\title{
Influence of the "Great Acceleration" of the Anthropocene on the fluxes of trace elements in sediments of the Santos and São Vicente estuarine system, southeastern Brazil
}

José Lourenço Friedmann Angeli ( $\square$ loaungeli14@gmail.com )

University of Sao Paulo: Universidade de Sao Paulo https://orcid.org/0000-0003-2086-2022

Julie Sartoretto

University of Sao Paulo: Universidade de Sao Paulo

Bianca Kim

University of Sao Paulo: Universidade de Sao Paulo

Paulo Ferreira

University of Sao Paulo: Universidade de Sao Paulo

Michel Mahiques

University of Sao Paulo: Universidade de Sao Paulo

Rubens Figueira

University of Sao Paulo: Universidade de Sao Paulo

\section{Research Article}

Keywords: Anthropocene, trace element fluxes, sediment records, Santos and São Vicente estuarine system.

Posted Date: May 7th, 2021

DOl: https://doi.org/10.21203/rs.3.rs-492507/v1

License: (c) (i) This work is licensed under a Creative Commons Attribution 4.0 International License. Read Full License 


\title{
Influence of the "Great Acceleration" of the Anthropocene on the fluxes of trace elements in sediments of the Santos and São Vicente estuarine system, southeastern Brazil
}

José Lourenço Friedmann Angeli*, Juliê Rosemberg Sartoretto, Bianca Sung Mi Kim, Paulo Alves de Lima Ferreira, Michel Michaelovitch de Mahiques, Rubens Cesar Lopes Figueira

Instituto Oceanográfico - Universidade de São Paulo (IOUSP). Address: Pça. do Oceanográfico. 191, Butantã, São Paulo, Brazil. Zip Code: 05508-120. Phone: +551130917182. *Corresponding author: louangeli@usp.br

\begin{abstract}
The worldwide evidence of human activities on the environment led the scientific community to recognize a new geologic time unit known as the Anthropocene. Since the twentieth century, the estuaries have been largely impacted by urbanization and industrialization needs driven by population and economic growth. To assess the contamination, provenance, and fluxes of trace elements ( $\mathrm{As}, \mathrm{Cr}, \mathrm{Cu}, \mathrm{Ni}, \mathrm{Pb}, \mathrm{Sc}, \mathrm{V}$ and $\mathrm{Zn}$ ) over the last century, a geochemical and chemometric technique was employed in sediment cores of the Santos and São Vicente Estuarine System (SSVES), an industrial and port region of international importance. The results indicated low contamination, with the highest enrichment factors $(\mathrm{EF})$ for $\mathrm{Cu}(\mathrm{EF}=3.1), \mathrm{Pb}(\mathrm{EF}=2.7), \mathrm{Zn}$ $(\mathrm{EF}=2.4)$ and As $(\mathrm{EF}=2.3)$ found next to the harbor area. The Pre-industrial records confirm the relatively high concentrations of As and its naturally enriched occurrence on the Brazilian shelf. Sediment accumulation rates and trace element fluxes showed a general increase over the years, since the early 1960s, associated with the "Great Acceleration" of the mid-twentieth century. These alterations are human-induced and include urbanization and industrialization. Nonetheless, as the contents and enrichment of trace elements indicate that the region is not severely polluted, we hypothesize that the contamination in the SSVES is likely related to the drainage and erosion of the urbanized adjacent area, rather than direct disposal of inorganic contaminants from the industrial activity.
\end{abstract}

\section{Keywords}

Anthropocene; trace element fluxes; sediment records; Santos and São Vicente estuarine system.

\section{Introduction}


The extensive impact of anthropogenic activities and their unique mark on geological records led the scientific community to debate the definition of a new geologic epoch, the Anthropocene (Crutzen and Stoermer 2000; Waters et al. 2016). The Anthropocene Working Group (AWG) of the Subcommission on Quaternary Stratigraphy (SQS) of the International Commission of Stratigraphy (ICS), established that the Anthropocene is stratigraphically distinct from the Holocene and, decided to its formalization as a new geochronologic unit, however the topic is currently under evaluation (Waters et al. 2016).

Although the man's influence on the environment is undeniable, the exact period in which the Anthropocene began is still a matter of debate. Initially, it was proposed that James Watt's invention of steam engine catalyzed the beginning of the Anthropocene, thus linking it directly to the Industrial Revolution (Crutzen and Stoermer 2000). These technological advances marked a shift from a long period of slow population growth, landscape modification by agricultural activities and energy use mainly from wood burning, to an interval of accelerated population growth, urbanization and industrialization driven by increased use of fossil fuels (Zalasiewicz et al. 2015).

Specifically, the period following end of World War II associated with rapid demographic expansion, paralleled by an increase in the global economy and associated environmental changes, is termed by many as the Period of the Great Acceleration. Zalasiewicz et al. (2015) proposed 1945 (Trinity explosion; the first nuclear test) as the GSSA (Global Standard Stratigraphic Age, i.e., the starting point) of the Anthropocene, due to the clear presence of artificial radionuclides from nuclear tests. However, the radioactive record in sediment cores in the South American coast of the South Atlantic Ocean suggest 1963 as a chronostratigraphic marker, in which the maximum fallout from the nuclear test is observed (Ferreira et al. 2016). Given that the studies by Zalasiewicz et al. (2015) and Ferreira et al. (2016) are based in precisely dated stratigraphic records, this study therefore, will follow this methodological approach.

During the "Great Acceleration", population doubled in just 50 years and the global economy increased by more than 15 -fold. Since 1960, petroleum demand increased by a factor of 3.5. Additionally, the number of vehicles rose significantly from approximately 40 million at the end of WWII to almost 700 million in 1996. Between 1950 and 2000, the world's population living in cities increased from 30 to 50\%, and this increasing trend continues (Steffen et al. 2007).

In this situation of worldwide environmental change, the coastal zone is significantly susceptible. Specific reasons include a high demographic and industrialized index, and the characteristic sustained growth and development of these regions over the past 150 years (Ramesh et al. 2015; Ontiveros-Cuadras et al. 2019). Moreover, estuarine and coastal systems receive significant fluvial inputs, as well as dissolved and particulate matter. As a result, anthropogenic fluxes of trace elements to estuaries and coastal zones have risen significantly, disrupting biogeochemical cycles (Andrade et al. 2017).

Metal contamination has been a worldwide focus of study due to its harmful impact on different ecosystems and, ultimately, human health (Birch 2018). In recent years, several studies have focused on metal concentrations and their distribution, historical trends, sources, and environmental fate (e.g., Chabukdhara and Nema 2012; Gonçalves et al. 2013; Kim et al. 2016; Angeli et al. 2019; Ontiveros-Cuadras et al. 2019. Varol et al. 2020; Manju et al. 2020; Álvarez-Vázquez et al. 2020). Studying the role of sediment in trapping different pollutants is essential in order to assess the ecological state of water environments.

The mid-twentieth century marked a rapid urbanization and a strong industrial developmental process in Brazil, resulting in substantial environmental impacts (Bregunce et al. 2011). These environmental impacts were more pronounced in estuaries and have been linked to port operations and urban and industrial waste dumps (Chakraborty et al. 2014). The Santos and São Vicente estuarine system (SSVES) is an example of this situation (Braga et al. 2000; Luiz-Silva et al. 2002). The estuarine system houses the largest port of Latin America, deemed the $39^{\text {th }}$ largest in terms of loading and unloading worldwide (CODESP 2011). For the maintenance of port operations, it is essential to drag the contaminated sediments of the Santos and Piaçaguera channels, resulting in the resuspension of pollutants and ultimately impacting the water quality and the biota. Previous studies showed a metal pollution problem (e.g., $\mathrm{Cu}, \mathrm{Pb}, \mathrm{Zn}$ ), especially at the upper estuary, where the main industrial complex (Cubatão Industrial Complex) of this region is located (Hortellani et al. 2008; Bordon et al. 2011; Gonçalves et al. 2013; Buruaem et al. 2013; Kim et al. 2016; Kim et al. 2019).

To understand the impact of increasing human influence, we studied two main aspects in this region: (i) the possible sources of trace elements in the SSVES, and (ii) the fluxes of trace elements during the Anthropocene. To address these features, dated sediment cores were analyzed combining a geochemical and chemometric approach. Therefore, the results from this study can be related to the new proposed geological 
epoch and may give insights into the influence of human activities as the major geological force in the Southeastern coast of Brazil.

\section{Material and methods}

\subsection{Study area and sampling}

The SSVES is located on the central coast of the State of São Paulo. Brazil $\left(23^{\circ} 90^{\prime}\right.$ S-24 $00^{\prime} \mathrm{S} .46^{\circ}$ $\left.30^{\prime} \mathrm{W}-46^{\circ} 50^{`} \mathrm{~W}\right)$, with the rainy season from October to April and the dry season extending from May to September. The climate is characterized as hot tropical humid. Three morphological sectors can be distinguished within the estuarine area: the Bertioga channel; Santos Bay and the upper estuary (Kim et al. 2019). In the upper estuary, several rivers transport the sediments from the Serra do Mar into the SSVES. Precambrian metamorphic rocks of granitic composition are the source of the sediments of this system (Perrota et al. 2005). Relatively complex hydrodynamics characterizes the estuarine environment, which receives sediments from the region's watershed, becoming particularly vulnerable to sedimentation and contaminants accumulation from nearby industrial areas (Abessa et al. 2008)

The study area has been characterized by high anthropogenic activity over the last 120 years, with the construction of the Port of Santos in 1896 and its expansion after the opening in the 1920s of the Henry Borden hydroelectrical plant (Martins et al. 2007; Jesus et al. 2020). Nonetheless, the urbanization and industrialization along the estuarine system, started around the 1950s with the beginning of the activities of the Cubatão Industrial Complex and the expansion of the Port of Santos (Luiz-Silva et al. 2008). The operation of a steelplant, with extensive production of caustic soda (employing the mercury cell technique), marked the 1960s. Fertilizer industries (phosphate and nitrogen-based products) appeared by the 1970s and, have already produced, as waste, about 69 million tons of phosphogypsum (Hortellani et al. 2008). Large quantities of solid waste discharges from domestic activities of the cities of Santos and São Vicente coincided with the fertilizer industries implantation (Martins et al. 2007). Moreover, both harbors of the steelplant and the main fertilizer industry are located into the estuary, where iron and phosphate ores are handled (Luiz-Silva et al. 2008). The processes of degradation of the estuarine system and the negative effects of pollution, would be reversed only from 1984, when an intensive environmental program was conducted to improve the environmental quality and control the air, water, and soil pollution (CETESB 2001). Despite the efforts to improve environmental quality in the 1980s, growth population, urbanization and industrialization continued to rise in the following years. Several studies have found that the estuarine system is still impacted by inorganic contaminants (LuizSilva et al. 2008; Hortellani et al. 2008; Torres et al. 2009; Bordon et al. 2011; Kim et al. 2016; Kim et al. 2019).

Currently, due to the Port of Santos expansion, dredging activities are required to maintain the navigation channel (Buruaem et al. 2013), which can lead to resuspension of sediments releasing the metals to the water column. Moreover, according to CETESB (2001), the industrial activities in the region can be grouped based on its products and trace metal potential emission. This grouping resulted in 1 steel plant with potential emission of $\mathrm{Cu}, \mathrm{Mn}, \mathrm{Ni}$ and $\mathrm{Zn} ; 2$ oil refineries with potential emission of $\mathrm{Cu}, \mathrm{Cr}, \mathrm{Ni}, \mathrm{Hg}$ and $\mathrm{Zn} ; 11$ chemical and petrochemical industries with potential emission of $\mathrm{Cd}, \mathrm{Cu}, \mathrm{Cr}, \mathrm{Mn}, \mathrm{Ni}, \mathrm{Pb}, \mathrm{Zn}$ and $\mathrm{Hg}$ and 7 fertilizer industries with potential emission of $\mathrm{Pb}, \mathrm{Ni}$ and $\mathrm{Zn}$.

In April 2012, four sediment cores were collected along the SSVES with a gravity core sampler. The position of the sampling stations is shown in Fig. 1, and their coordinates and core information are given in Table S1 in Supplementary Material. The cores were fractionated into $2 \mathrm{~cm}$ thick slices and freeze-dried.

\subsection{General analyses}

In order to quantify the mud fraction (clay + silt; $<0.063 \mathrm{~mm}$ ), grain size analysis was conducted by subjecting the samples to wet sieving in a $0.063 \mathrm{~mm}$ mesh sieve. This technique was chosen because most contaminants are adsorbed on the fine grains, where the contact surface is larger (Förstner e Salomons 1980). Variation in element concentrations as a function of sediment grain size is attributed to differences in their adsorption potential on clay minerals, metal oxides, and organic matter, which tend to be concentrated in smaller aggregates (Kersten e Förstner 1995). 
Bulk samples were subjected to a partial acid digestion technique following the SW 846 US EPA 3050B method (USEPA 1996). This method dissolves the "environmental available" elements, such as those bound to the organic matter, carbonates, and Fe/Mn oxides and adsorbed onto fine-grain particles, excluding those linked to the silicate structure. Trace elements ( $\mathrm{As}, \mathrm{Cr}, \mathrm{Cu}, \mathrm{Ni}, \mathrm{Pb}, \mathrm{Sc}, \mathrm{V}$ and $\mathrm{Zn}$ ) were analyzed using inductively coupled plasma optical emission spectrometry (ICP-OES) and their levels are presented in Table S2, S3, S4 and S5 of the Supplementary Material. A certified reference material (SS-2 from EnvironMAT ${ }^{\mathrm{TM}}$ CRM SPC Science) was used to validate the precision and accuracy of trace element determination and the results are given in Table 1.

The activities of ${ }^{210} \mathrm{~Pb}$ and ${ }^{226} \mathrm{Ra}$ were determined by high-resolution gamma spectrometry in lowbackground high pure Ge gamma spectrometer (EG\&G ORTEC. model GMX25190P). Sedimentation rates and core dating were calculated from ${ }^{210} \mathrm{~Pb}_{\mathrm{xs}}$ according to previous works (Figueira et al. 2007; Ferreira et al. 2013).

\subsection{Dating model. mass accumulation rates (MAR) and trace element fluxes}

The CRS (Constant Rate of Supply) model (Appleby and Oldfield 1978) was used to determine the age models and mass accumulation rates (MAR, $\mathrm{g} \mathrm{cm}^{-1} \mathrm{yr}^{-1}$ ). This model assumes that a constant rate of ${ }^{210} \mathrm{~Pb}_{\mathrm{xs}}$ is supplied, and the sedimentation is time-dependent. Corroboration of the ${ }^{210} \mathrm{~Pb}$ chronology was achieved using the weapon fallout ${ }^{137} \mathrm{Cs}$. The activity levels of each core are given in Table S6, S7, S8 and S9 in the Supplementary Material.

Based on the excess ${ }^{210} \mathrm{~Pb}\left({ }^{210} \mathrm{~Pb}\right.$ xs $)$ activity profiles, mass accumulation rates (MAR) were determined. The mass accumulation rates can be shown in the following formula:

$$
\varphi(z)=\frac{1}{\lambda}\left[\frac{I(A)_{t o t}-I(A)_{z}}{(A)_{z}}\right]
$$

Where, $\varphi$ is the mass accumulation rate at depth $z ; \lambda$ is the constant decay for ${ }^{210} \mathrm{~Pb}\left(0.0311 \mathrm{yr}^{-1}\right) ; I$ $(A)_{\text {tot }}$ is the full inventory; $I(A)_{z}$ is the inventory from the top until depth $z$ and; $(A)_{z}$ is the ${ }^{210} \mathrm{~Pb}_{\mathrm{xs}}$ activity at depth $z$.

According to Cochran et al. (1998), we calculated element fluxes through the multiplication of the mass accumulation rate by the element concentration with the following formula:

$$
F i=S i[M e]
$$

Where $\mathrm{Fi}=$ metal flux at $\mathrm{i}$ interval $\left(\mu \mathrm{g} \mathrm{g}^{-2} \mathrm{~cm}^{-2} \mathrm{yr}^{-1}\right), \mathrm{Si}=$ the accumulation rate derived from ${ }^{210} \mathrm{~Pb}$ method $\left(\mathrm{g} \mathrm{cm}^{-2} \mathrm{yr}^{-1}\right)$ for the $\mathrm{i}$ interval and $\mathrm{Me}=$ metal concentration $\left(\mu \mathrm{g} \mathrm{g}^{-1}\right)$.

\subsection{Assessment of contamination}

Sediment quality guidelines (SQGs), such as the Brazilian legislation for the classification of dredged sedimentary materials CONAMA 454/2012 (CONAMA 2012) were used in this research, to assess the quality of the sediments. The thresholds levels are given in Table 2, where Level 1 is the level at which no harmful effect on the biological community is detected and Level 2 is the level at which adverse effects might arise within the biological community.

The evaluation of the contamination status of the SSVES, was determined through the calculation of the Enrichment Factor (EF) (Zoller et al. 1974). The EF is calculated as follows:

$$
E F=\frac{\left(\frac{M}{X}\right)_{\text {sample }}}{\left(\frac{M}{X}\right)_{\text {background }}}
$$


Where, $\mathrm{M}$ is the concentration of the element of concern and $\mathrm{X}$ is the concentration of the normalizing element. By convention. if $0.5 \leq \mathrm{EF} \leq 1.5$, the trace element is provided as a weathering product from crustal rocks; meanwhile, an EF > 1.5 indicates an anthropogenic contribution (Zhang and Liu 2002).

Differences in in grain size and mineralogy were compensated by normalization with a conservative element (i.e., $\mathrm{Li}, \mathrm{Al}, \mathrm{Ti}, \mathrm{Fe}$ or $\mathrm{Sc}$ ). The element $\mathrm{Sc}$ was selected as the reference element for normalization due to its lithogenic and conservative nature and strong association with the fraction of fine-grain sediments (UNEP 1995) (Table S6; Supplementary Material). Background levels (BL) were assessed by using the mean trace element contents of 5 deepest samples from the bottom of each core. These samples, considering the chronology, represent pre-industrial conditions.

\subsection{Statistical analyses}

Chemometrics can be a valuable tool in environmental studies, especially considering the large amounts of data generated with the geochemical analyses and the complexity of the processes under investigation. Thus, to study the relationship between the elements and identify processes that affect the sediment trace element contents, Pearson's correlation coefficients and Principal Component Analysis (PCA) were carried out on the dataset of each sediment core. The PCA was conducted to investigate the interrelationships between variables and to evaluate the possible sources of trace elements. Many researchers (Rubio et al. 2000; Filgueiras et al. 2004; Geng et al. 2015; Varol et al. 2020; Hosokawa et al. 2020; Angeli et al. 2020) have used this technique in the evaluation of environmental data. Statistical analyses were conducted in R Software (RCoreTeam, 2017).

\section{Results and discussion}

\subsection{Mud content distribution}

The mud content (defined as the sum of silt + clay) shows that the core from Santos (S1) is almost entirely composed of mud with little variation in content ( $86.95 \%$ on average) from the bottom of the core until $42 \mathrm{~cm}$ depth, where a marked decrease is observed, reaching levels of approximately $25 \%$ in the top sediment layers (Fig.2). The core from Cubatão (core S2) was predominantly mud and showed a marked decrease in mud content at $20 \mathrm{~cm}$ towards the top. These changes in the depositional characteristics in both cores can be related to the hydrodynamics properties of the area. Dredging operations in the early 1970s resulted in stronger current activity, favouring the deposition of coarser sediments in the area (Jesus et al. 2020). In São Vicente, cores S3 and S4 present a percentage of sands higher than muds. In these cores the content of mud was $43.8 \pm$ 11.5 and $23.2 \pm 11.5$, respectively.

\subsection{Mass accumulation rates and trace elements fluxes}

The results obtained from the calculation using CRS model for ages and accumulation rates in the cores from the SSVES are presented in supplementary table S2, S3, S4 and S5. The CRS model was applied until $130 \mathrm{~cm}$ depth for core $S 1$, until $100 \mathrm{~cm}$ for $S 2,90 \mathrm{~cm}$ for $\mathrm{S} 3$ and $90 \mathrm{~cm}$ for core $\mathrm{S} 4$. The sedimentation rates varied from 0.06 to $2.10 \mathrm{~cm} \mathrm{yr}^{-1}$ in core $\mathrm{S} 1$; from 0.07 to $1.96 \mathrm{~cm} \mathrm{yr}^{-1}$ in core $\mathrm{S} 2$; from 0.10 to $2.56 \mathrm{~cm}$ $\mathrm{yr}^{-1}$ in core $\mathrm{S} 3$ and; from 0.01 to $1.47 \mathrm{~cm} \mathrm{yr}^{-1}$ in core $\mathrm{S} 4$.

The evolution of MARs for all cores is presented in Fig. 3. The MARs varied from 0.04 to $1.83 \mathrm{~g} \mathrm{~cm}^{-}$ ${ }^{2} \mathrm{yr}^{-1}$ in core $\mathrm{S} 1$; from 0.09 to $3.19 \mathrm{~g} \mathrm{~cm}^{-2} \mathrm{yr}^{-1}$ in core $\mathrm{S} 2$; from 0.07 to $1.68 \mathrm{~g} \mathrm{~cm}^{-2} \mathrm{yr}^{-1}$ in $\mathrm{S} 3$ and from 0.01 to $1.92 \mathrm{~g} \mathrm{~cm}^{-2} \mathrm{yr}^{-1}$ in core $\mathrm{S} 4$.

The results indicate that the deposition of sediments varied both between sampling stations and time. Located next to the Cubatão Industrial Complex, core S2 showed the highest sediment flux $\left(3.19 \mathrm{~g} \mathrm{~cm}^{-2} \mathrm{yr}^{-1}\right)$ around 2010. Converting the mass accumulation rate to sedimentation rate, results in approximately $1.69 \mathrm{~cm}$ $\mathrm{yr}^{-1}$. This value is higher than those found in previous studies in the same area (Tessler et al. 2006; Gonçalves et al. 2013). The increased sedimentation since the early 1970s may be attributed to the Cubatão Industrial Complex accelerated urbanization and industrial growth and the expansion of port operations (Luiz-Silva et al. 2008; Bordon et al. 2011). 
Next, we assessed trace elements fluxes using MAR and element concentration to gain insights into the accumulation of the elements over time (Fig. 4). To achieve this, we used only dated layers of the cores (130 cm depth for S1; $100 \mathrm{~cm}$ for S2; $90 \mathrm{~cm}$ for S3 and $80 \mathrm{~cm}$ for S4) spanning time-intervals from 1905, 1920, 1932 and 1887, to the present, allowing us to measure these fluxes. In general, all cores showed an increased trend in trace element fluxes.

Both human influence and storms or other high flow occurrences might reflect the high mass accumulation rates. Heavy rainfall is typical in the studied area leading to many landslides in the Serra do Mar Mountain chain, as recorded in 1967, 1971, 1976 and 1999 (Gramani et al. 2001; Kanji et al. 2003). Since core S2 is close to the Serra do Mar, sediment deposition appears to have been influenced by these mass movements. Moreover, fluvial waters from the rivers of the Serra do Mar arrive specifically in the port channel, where cores S1 and S2 are located (Tessler et al. 2006).

The marked peaks in trace element fluxes in the cores closest to the Port of Santos (S1 and S2) in the early 1970s coincide with the port expansion. In the early 70s, a great expansion in the Port of Santos took place. In comparative terms, 2314 meter of docks were built in the previous 60 years, while during 1969 to 1976 the port expanded 3812 meters (Zundt 2006). In the 1980s, the relatively lower trace element fluxes are associated with the introduction of emission controls implemented in the SSVES by most industries. It is plausible that the pollution management has resulted in better waste treatment and decreased input of inorganic pollutants into this region.

Despite the trace element fluxes decrease in the 80s, these fluxes rose during the following decades, caused by the growing number of industries and urbanization. By 1999, the cities of Santos and São Vicente had approximately 800.000 inhabitants (IBGE 2000), in which approximately $10 \%$ emitted their untreated effluents directly into the estuary. Additionally, tourism doubles the number of inhabitants in the summer (Martins et al. 2007). Thus, after successive rainfalls, the runoff from this region contributes to the input of inorganic contaminants to the SSVES.

\subsection{Evaluation of trace element contamination}

The mean, standard deviation, and range of concentration for all analyzed elements, along with, a comparison with studies performed in other regions and the thresholds established by the Brazilian legislation (CONAMA 454/2012) (CONAMA 2012) are presented in Table 2, as well as the regional Background Levels (BL). The Background was calculated as the average of the last 5 samples of the bottom of each sediment core, these samples are representative of natural concentrations, and therefore, can be considered pre-Anthropocene levels.

The element concentrations $\left(\mathrm{mg} \mathrm{kg}^{-1}\right)$ showed a moderate variation. Compared to metal concentrations reported in surface sediments and sediment cores in other Brazilian coasts (Table 2), the present concentrations were relatively low. Trace element concentrations found in this study were comparable with a previous research conducted in the SSVES (Kim et al. 2018) and Paranaguá Bay (Angeli et al. 2020), another important port impacted area. The trace element concentrations were also, comparable to the levels found in the Caravelas estuary (Angeli et al. 2019) and Todos os Santos Bay (Hatje and Barros 2012), both located on Northeastern Brazilian coast and considered relatively preserved, despite the latter showing significant levels of $\mathrm{Zn}$ contamination. Furthermore, despite the differences in analytical methods used, trace elements in the SSVES were much lower than in Guanabara Bay (Aguiar et al. 2016), considered one of the most impacted estuaries of Brazil.

Since the sediment samples are composed of whole sediment samples, they present different granulometric features. Thus, it is normal to report a significant level of variation. Furthermore, the range of variation of background levels found in this study confirms the importance of assessing regional BLs, rather than use global values, since the latest does not account for regional variability and chemical heterogeneity (Birch 2017).

The measured concentrations were compared with the predicted values for dredging material established by Brazilian legislation (CONAMA 2012). The levels of $\mathrm{Cr}, \mathrm{Cu}, \mathrm{Ni}, \mathrm{Pb}$ and $\mathrm{Zn}$ were below Level 1. Therefore, based on these results, we may assume that these sediments are not potentially harmful to the biota. Nonetheless the highest levels were found in the core samples from the upper estuary (S2) next to the 
industrial complex. The levels of As were also, highest in the upper estuary, presenting values greater than the Level 1, but all below Level 2.

In general, no significant enrichment was observed in the cores from SSVES, with EF values around 1.5 (Fig. 5), indicating no significant contamination by trace elements in the SSVES. Core S1 showed a moderate enrichment for As in the early 1950s towards the top of the core. $\mathrm{Cr}$ and Ni showed no enrichment in all sediment cores analyzed.

Elements whose biogeochemical cycles can be influenced by anthropogenic activities in the estuarine system, such as $\mathrm{Cu} \mathrm{Pb}$ and $\mathrm{Zn}$ showed moderate enrichments at the top of the cores, which correspond to the early 1990s (with the exception of core S4). The three metals showed similar behavior in all sampling stations. Despite the environmental programs conducted in the 1980s, the most likely answer for these profiles is the increase of anthropogenic inputs during the following years caused by intense urbanization and industrialization. Many authors have reported high concentrations of these elements coexisting in the environment due to similar chemical properties and use (e.g., Al Rashdi et al. 2015; Jiang et al. 2013; Liu et al. 2015).

\subsection{Sources of trace elements in the SSVES}

The correlation coefficients among the different elements ( $\mathrm{As}, \mathrm{Cr}, \mathrm{Cu}, \mathrm{Ni}, \mathrm{Pb}, \mathrm{Sc}, \mathrm{V}$ and $\mathrm{Zn}$ ) and the mud content in all sediment cores are shown in supplementary Table S7. In general, the cores showed significant positive correlations between $\mathrm{Sc}, \mathrm{V}$, and mud content. This high correlation is expected since these elements tend to be rapidly removed from the solution by interaction with the surfaces of sinking particles. The correlations between all metals was highest in core S4, indicating that the observed element deposition and accumulation in this region of the estuarine system were most influenced by the geochemical composition of the catchment area and the weathering of the rocks. Weaker positive correlation coefficients were found for $\mathrm{As}, \mathrm{Cu}, \mathrm{Pb}$, and $\mathrm{Zn}$, in cores $\mathrm{S} 1, \mathrm{~S} 2$, and $\mathrm{S} 3$. The weaker correlation of As, when compared to the other elements, maybe due to its metalloid nature. Meanwhile, the weaker correlation of $\mathrm{Cu}, \mathrm{Pb}$ and $\mathrm{Zn}$ with the conservative elements could represent a different source. Association between $\mathrm{Cu}, \mathrm{Pb}$ and $\mathrm{Zn}$ has also been identified in previous studies (Bordon et al. 2011; Buruaem et al. 2013; Tramonte et al. 2016; Tramonte et al. 2018; Salaroli et al. 2018; Kim et al. 2019) in the sediments of the SSVES and adjacent areas.

The multivariate technique of principal component analysis (PCA) was performed to the matrix of 10 variables (total concentration of $\mathrm{As}, \mathrm{Cr}, \mathrm{Cu}, \mathrm{Fe}, \mathrm{Ni}, \mathrm{Pb}, \mathrm{Sc}, \mathrm{V}$ and $\mathrm{Zn}$ ) to minimize the data dimensions into two components that could describe the distribution of the elements within each core.

High loads for almost all elements in all studied cores was found in the Principal component 1 (PC1) (Fig. 3). It comprises $71 \%$ of the variance for core S1, 74\% for S2, 79\% for S3 and $95 \%$ for S4. The high correlation of Sc, $\mathrm{V}$ and mud content suggests that this component is mainly lithogenic. The erosion of alkaline rocks, which contain $\mathrm{Sc}, \mathrm{V}$ and $\mathrm{Ni}$, is accounted to be the primary source of sediments in the studied area. Furthermore, $\mathrm{Cr}$ levels, EFs and steady behavior along the sediment cores suggest its presence in minerals such as migmatite and chromite, which are resistant to weathering and dissolution (Abreu 1973).

The relatively high concentrations of As and its presence, particularly in the PC1, confirm that the weathering of rocks could be a major source of this element. Arsenic is naturally enriched in the region (Gonçalves et al. 2013; Silva et al. 2011; Kim et al. 2018), several studies have found high arsenic background levels along the entire Brazilian coast (Mirlean et al. 2012; Cagnin et al. 2017; Baeyens et al. 2019; Angeli et al. 2019). Despite these high As background levels, several anthropogenic impacts along the coast, which include releases from metallurgical industries, gold and iron mining and phosphate fertilizer plants, are observed (Baeyens et al., 2019). In the Doce River continental shelf, on Brazilian eastern coast, high As enrichments were attributed to iron and gold mining exploitation (Cagnin et al. 2017). In estuarine and lagoonal systems located in Brazil southern coast, As enrichments were found next to port terminals and related to the presence of fertilizer producing plants (Mirlean and Roisemberg 2006; Sá et al. 2015; Angeli et al 2020). In the SSVES, fertilizer plants, established in the 1970s, have been operating along the margins of some rivers and disposing a large quantity of phosphogypsum, approximately 400 ton per day, as piles in adjacent storage areas. (Oliveira et al. 2007). Thus, it is possible that increasing As enrichments in the study area are related to the fertilizer plants and the phosphogypsum ponds. 
Principal component 2 (PC2) accounted for $11 \%$ of the variance for core S1, 10\% for S2, 14\% for S3, and only $3 \%$ for core S4. Anthropogenic effects are expressed by this component, since it presented higher loadings of pollutants, such as $\mathrm{Cu}, \mathrm{Pb}$ and $\mathrm{Zn}$. This component showed a higher correlation with $\mathrm{Cu}$ and $\mathrm{Pb}$ in core $\mathrm{S} 1, \mathrm{~Pb}$ and $\mathrm{Zn}$ in core $\mathrm{S} 2, \mathrm{Cu}$ and $\mathrm{Zn}$ in core $\mathrm{S} 3$, while in core $\mathrm{S} 4$ none of the analyzed elements showed a strong correlation with this component.

Copper is found in effluents at the Cubatão Industrial Complex, from several industries and can be discharged into the estuary as untreated sewage (CETESB 2001). Zinc can be employed in its metallic or salt form, may have significant anthropogenic sources, since it can be found in the effluent of most industries in the region, in port terminals as well as, in the domestic sewage (CETESB 2001; Golçalves et al. 2013). Moreover, boat traffic and repair areas are significant causes of $\mathrm{Cu}$ and $\mathrm{Zn}$ release (Turner 2010; Costa and Wallner-Kersanach 2013). Several anthropogenic sources for $\mathrm{Pb}$ in the area including metal extraction, beneficiation and smelting, oil refining, petrochemical, steel, and fertilizer industries difficult the precise determination of the source of this metal (Kim et al. 2018). Nevertheless, cores S1 and S2 are close to the Alemoa oil terminal, which has been supplied and exported oil since 1951. Moreover, since 1960, loading and unloading of chemical products have often occurred on the east side where storage tanks are found (Martins et al. 2010).

There is a well-documented record of historic emission trends around the world (Steffen et al., 2007; Zalasiewicz et al. 2015; Water et al. 2016). These anthropogenic signals progressively gained strength during the mid-20 $20^{\text {th }}$ century and are associated to extreme growth of human influence during the stage of the Anthropocene called the Great Acceleration (Ludwig and Steffen 2018; Bibi et al. 2020) However the potential markers for the onset of this activity are not synchronous and highly variable. Southern Hemisphere atmospheric ${ }^{14} \mathrm{C}$, suggest 1965 as the peak of radionuclides produced during nuclear bomb tests (Turney et al. 2018). Moreover, the radioactive record in sediment profiles in the South American coast of the South Atlantic suggest 1963 as a chronostratigraphic marker, regarding the deposition of fallout radioactivity (Ferreira et al. 2016). Therefore, the chronological and geochemical signals of Santos and São Vicente estuarine system provide strong evidence that allow us to confirm the early 1960s (Ferreira et al. 2016; Turney et al. 2018) as the base of the Great Acceleration of the Anthropocene in the South Atlantic.

\section{Conclusions}

This research underlined the significance of using geochemical and chemometrics approaches combined with the ${ }^{210} \mathrm{~Pb}$ dating to understand the sources and evolution of trace elements during the Anthropocene.

The contamination assessment revealed that most of the analyzed trace elements did not present high contamination levels, with average values below thresholds established by Brazilian legislation. Enrichment Factors (EFs) suggest there are contamination levels for $\mathrm{As}, \mathrm{Cu}, \mathrm{Pb}$ and $\mathrm{Zn}$, at the uppermost layers of the sediment cores located in the port area and upper estuary. The high levels of As at the bottom of the sediment cores, corresponding to pre-Anthropocene levels, confirm the high natural background levels of this element in the Brazilian coast. Nonetheless, the increasing enrichment trend could be a result of the development of fertilizer plants in the region during more recent years.

The sediment accumulation rates, and trace element fluxes showed an accumulation tendency starting in the early $60 \mathrm{~s}$. The increased accumulation of these trace elements can be associated to the mid- $20^{\text {th }}$ century "Great Acceleration". This process is accompanied by the increased urbanization and industrialization needs of that period that resulted in the erosion and drainage of the urbanized area. Important to note that, in the 1980s a marked decrease in trace element fluxes was achieved due to the implementation of environmental programs. However, despite these efforts, the fluxes and enrichment of trace elements resumed the increasing trend in the following years.

According to the correlation and PCA analyses, most of the trace elements in the sediments of the SSVES have a natural lithogenic source, suggesting that they are transported, and adsorbed into fine-grained particles through weathering and erosion processes. On the other hand, $\mathrm{Cu}, \mathrm{Pb}$ and, $\mathrm{Zn}$ results suggest anthropogenic influence. Our results also indicate that the region is not severely contaminated. These findings allow us to indicate that the contamination in the SSVES is closely related to the drainage from the adjacent urbanized area and the erosive processes rather than man-made disposal of inorganic contaminants. 


\section{Acknowledgments}

This study was supported in part by the Coordenação de Aperfeiçoamento de Pessoal de Nível Superior - Brasil (CAPES) - Finance Code 001 and from FAPESP ( ${ }^{\circ} .2009 / 01211-0 ; n^{\circ} .2011 / 50581-4$ and $n^{\circ}$ 2017/08987-0). Oceanographic Institute of University of São Paulo (IOUSP). and Laboratory of Inorganic Marine Chemistry (LaQiMar).

\section{Conflict of interest}

The authors declare that they have no conflict of interest.

\section{References}

Abessa DMS, Carr RS, Sousa ECPM, Rachid BRF, Zaroni LP, Gasparro MR, Pinto YA, Bícego MC, Hortellani MA, Sarkis JES, Muniz P (2008) Integrative ecotoxicological assessment of contaminated sediments in a complex tropical estuarine system. In: T.N. Hoffer. (Org.). Marine Pollution: New Research. New York City: Nova Science Publishers Inc. pp.1-36.

Abreu SF (1973) Recursos minerais do Brasil, 2 ed. EUSP, São Paulo.

Aguiar VMC, Lima MN, Abuchacra RC, Abuchacra PFF, Baptista Neto JA, Borges HV, Oliveira VC (2016) Ecological risks of trace metals in Guanabara Bay, Rio de Janeiro, Brazil: An index analysis approach. Ecotox Eviron Safe 133:306-3015.

Al-Rashdi S, Arabi AA, Howari FM, Siad A (2015) Distribution of heavy metals in the coastal area of Abu Dhabi in the United Arab Emirates. Mar. Pollut. Bull. 97:494-498. http://doi.org/10.1016/j.marpolbul.2015.05.052

Ávarez-Vázquez MA, Álvarez-Iglesias P, Uña-Álvarez E, Quintana B, Caetano M, Prego R (2020) Industrial supply of trace elements during the "Anthropocene": A record in estuarine sediments from the Ria of Ferrol (NW Iberian Peninsula). Mar Chem 223:103825. https://doi.org/10.1016/j.marchem.2020.103825

Andrade RLB, Hatje V, Masqué P, Zurbrick CM, Boyle EA, Santos WPC (2017). Chronology of anthropogenic impacts reconstructed from sediment records of trace metals and $\mathrm{Pb}$ isotopes in Todos os Santos Bay (NE Brazil). Mar Pollut Bull 125(1-2):459-471. https://doi.org/10.1016/j.marpolbul.2017.07.053

Angeli JLF, Rubio B, Kim BSM, Ferreira PAL, Siegle E, Figueira RCL (2019) Environmental changes reflected by sedimentary geochemistry for the last one hundred years of a tropical estuary. J Mar Sys 189:3649. https://doi.org/10.1016/j.jmarsys.2018.09.004

Angeli JLF, Kim BSM, Paladino IM, Nagai RH, Martins CC, Mahiques MM, Figueira RCL (2020) Statistical assessment of background levels for metal contamination from a subtropical estuarine system in the SW Atlantic (Paranaguá Estuarine System. Brazil). J Sediment Environ 5:137-150.

Appleby PG, Oldfield F (1978) The calculation of lead-210 dates assuming a constant rate of supply of unsupported ${ }^{210} \mathrm{~Pb}$ to the sediment. Catena. 5:1-8. https://doi.org/10.1016/S0341-8162(78)80002-2

Bayens W, Mirlean N, Bundschuh J, de Winter N, Baisch P, Silva Júnior FMR, Gao Y (2019) Arsenic enrichment in sediment and beaches of Brazilian coastal waters: A review. Sci Tot Environ 681:143-154. https://doi.org/10.1016/j.scitotenv.2019.05.126

Bibi M, Wargreich M, Iqbal S (2020) Trace metals as markers for historical anthropogenic contamination: Evidence from the Peshawar Basin, Pakistan. Sci Tot Environ 703:2020. https://doi.org/10.1016/j.scitotenv.2019.134926 
Birch GF (2017) Determination of sediment metal background concentrations and enrichment in marine environments - A critical Review. Sci Tot Environ 580:813-831. http://dx.doi.org/10.1016/j.scitotenv.2016.12.028

Birch GF (2018) A review of chemical-based sediment quality assessment methodologies for the marine environment. Mar Pollut Bull 133:218-232. https://doi.org/10.1016/j.marpolbul.2018.05.039

Bordon ICAC, Sarkis JES, Gobbato GM, Hortellani MA, Peixoto CM (2011) Metal concentration in sediments from the Santos Estuarine System: a Recent Assessment. J Braz Chem Soc 22(10):1858-1865.

Braga ES, Bonetti CVDH, Burone L, Bonetti Filho J (2000) Eutrophication and bacterial pollution caused by industrial and domestic wastes at Baixada Santista estuarine system. Brazil. Mar Pollut Bull 40:165-173. https://doi.org/10.1016/S0025-326X(99)00199-X

Bregunce DT, Jordan EJ, Dziedzic M, Maranho LT, Aparecida Cubas AS (2011) Evaluation of the water quality of the Müller's Ribeirão. Curitiba-PR. Braz J Wat Res 16:39-47. https://doi.org/10.21168/rbrh.v16n3.p39-47

Buruaem LM, Castro IB, Hortellani MA et al (2013). Integrated quality assessment of sediments from harbour areas in Santos-São Vicente Estuarine System. Southern Brazil. Estuar Coast Shelf Sci 130:179-189.

Cagnin RC, Quaresma VS, Chaillou G, Franco T, Bastos AC (2017) Arsenic enrichment in sediments in the Eastern continental shelf of Brazil. Sci. Tot. Environ. 607-608:304-316. http://dx.doi.org/10.1016/j.scitotenv.2017.06.162

CETESB (Companhia de tecnologia de saneamento ambiental) (2001) Santos and São Vicente Estuarine System - Technical Report. https://cetesb.sp.gov.br/praias/publicacoes-relatorios/. Accessed 17 October 2018 (in Portuguese)

Chabukdhara M, Nema AK (2012) Assessment of heavy metal contamination in Hindon River sediments: A chemometric and geochemical approach. Chemosphere 87:945-953. doi: 10.1016/j.chemosphere.2012.01.055

Chakraborty P, Ramteke D, Chakraborty S, Nagender Nath B (2014) Changes in metal contamination levels in estuarine sediments around India - an assessment. Mar Pollut Bull 78:15-25. https://doi.org/10.1016/j.marpolbul.2013.09.044

Cochran JK, Hirschberg DJ, Wang J, Dere C (1998) Atmospheric deposition of metals to coastal waters (Long Island Sound. New York. USA): evidence from salt- marsh deposits. Estuar Coast Shelf Sci 46:503-522.

CODESP (Companhia Docas do estado de São Paulo) (2011) Port of Santos: Annual Report 2011. http://201.33.127.41/down/relatorio/Relatorio2011.pdf. Accessed 17 October 2018.

CONAMA. Conselho Nacional do Meio Ambiente. Resolução n.454. 2012. Estabelece as diretrizes gerais e os procedimentos referenciais para o gerenciamento do material a ser dragado em águas sob jurisdição nacional. Available at: http://www.mma.gov.br/port/conama/legiabre.cfm?codlegi=693

Costa LF, Wallner-Kersanach M (2013) Assessment of the labile fractions of copper and zinc in marinas and port areas in Southern Brazil. Environ Monit Assess185:6767-6781. DOI 10.1007/s10661-013-3063-0

Crutzen PJ, Stoermer EF (2000) The “Anthropocene”. Global Change Newsletter, 41:17-18.

Ferreira PAL, Ribeiro AP, Nascimento MG, Martins CC, Mahiques MM, Montone RC, Figueira RCL (2013). ${ }^{137} \mathrm{Cs}$ in marine sediments of Admiralty Bay. King George Island Antarctica. Sci Tot Environ 443:505-510. http://doi.org/10.1016/j.scitotenv.2012.11.032

Ferreira PAL, Figueira RCL, Siegle E, Neto NEA, Martins CC, Schettini CAF, Maciel PM, García-Rodriguez, F, Mahiques MM (2016). Using a cesium-137 (137Cs) sedimentary fallout record in the South Atlantic Ocean as a supporting tool for defining the Anthropocene. Anthropocene, 14, 34-45. 
Figueira RCL, Tessler MG, Mahiques M M, Fukumoto MM (2007) Is there a technique for the determination of sedimentation rates based on calcium carbonate content? A comparative study on the Southeastern Brazilian shelf Soils Found. 47:649-656. https://doi.org/10.3208/sandf.47.649

Filgueiras AV, Lavilla I, Bendicho C (2004) Evaluation of distribution. mobility and binding behaviour of heavy metals in surficial sediments of Louro River (Galicia. Spain) using chemometric analysis: a case study. Sci Total Environ 330. 115-129. doi: 10.1016/j.scitotenv.2004.03.03

Förstner U, Salomons W (1980) Trace metals analysis on polluted sediments Part I: Assessments of sources and intensities. Environ. Technol. Lett. 1:495-505. https://doi.org/10.1080/09593338009384006

Geng J, Wang Y, Luo H (2015) Distribution. sources. and fluxes of heavy metals in the Pearl River Delta. South China. Mar Pollut Bull 101:914-921. http://dx.doi.org/10.1016/j.marpolbul.2015.10.066

Gonçalves C, Figueira RCL, Sartoretto JR, Salaroli AB, Ribeiro AP, Ferreira PAL, Mahiques MM (2013) Reconstruction of historical trends in potentially toxic elements from sediment cores collected in Bertioga Channel. southeastern Brazil. Braz J Oceanogr. 61(2):149-160. http://doi.org/10.1590/S1679$\underline{87592013000200007}$

Gramani MF, Kanji MA (2001) Inventário e análise das corridas de detritos no Brasil. In: Anais da $3^{\circ}$ Conferência Brasileira sobre Estabilidade de Encostas. Rio de Janeiro. RJ.

Hatje V, Barros F (2012) Overview of the 20th century impact of trace metal contamination in the estuaries of Todos os Santos Bay: Past, Present and future scenarios. Mar Pollut Bull 64:2603-2614. $\underline{\text { https://doi.org/10.1016/j.marpolbul.2012.07.009 }}$

Hortellani MA, Sarkis JES, Abessa DMS, Sousa ECPM (2008) Assessment of metallic element contamination in contamination in sediments from the Santos - São Vicente estuarine System. Quim Nova 31:10-19. $\underline{\text { http://doi.org/10.1590/S0100-40422008000100003 }}$

Hosokawa S, Naito R, Nakamura Y (2020) Spatial patterns of concentrations of $\mathrm{Cu}$. Zn. Cd and $\mathrm{Pb}$ in marine sediments from Japanese port areas. Reg Stud Mar Sci. 35:101135. https://doi.org/10.1016/j.rsma.2020.101135

IBGE (Instituto Brasileiro de Geografia e Estatística).2000. Available at: http://www.ibge.gov.br

Jesus MSS, Frontalini F, Bouchet VMP, Yamashita C, Sartoretto JR, Figueira RCL, Sousa SHM (2020) Reconstruction of the palaeo-ecological quality status in an impacted estuary using benthic foraminifera: The Santos Estuary (São Paulo state. SE Brazil). Mar Environ Res $162 . \quad 105121$. https://doi.org/10.1016/j.marenvres.2020.105121

Jiang J, Wang J, Liu S, Lin C, He M, Liu X (20130 Background. baseline. normalization. and contamination of heavy metals in the Liao River Watershed sediments of China. J Asian Earth Sci 73:87-94. $\underline{\text { http://doi.org/10.1016/j.jseaes.2013.04.014 }}$

Kanji MA, Massad F, Cruz PT (2003) Debris flows in areas of residual soil: occurrence and characteristics. In: Abstract of the International Workshop on Occurrence and Mechanism of Flows in Natural Slopes and Earthfills. Sorrento. Italy.

Kersten M, Forstner U (1995) Speciation of trace metals in sediments and combustion waste. In: Ure AM. Davidson CM (eds) Chemical speciation in the environment. Chapman \& Hall. Glasgow 234-275.

Kim BSM, Salaroli AB, Ferreira PAL, Sartoretto JR, Mahiques MM, Figueira RCL (2016) Spatial distribution and enrichment assessment of heavy metal in surface sediments form Baixada Santista. Southeastern Brazil. Mar Pollut Bull 103:333-338. http://dx.doi.org/10.1016/j.marpolbul.2015.12.041

Kim BSM, Angeli JLF, Ferreira PAL, Mahiques MM, Figueira RCL (2018) Critical evaluation of different methods to calculate the Geoaccumulation Index for environmental studies: A new approach for Baixada Santista - $\quad$ Southeastern Brazil. Mar. Pollut. Bull. 127. 548-552. https://doi.org/10.1016/j.marpolbul.2017.12.049 
Kim BSM, Angeli JLF, Ferreira PAL, Mahiques, MM, Figueira RCL (2019) A multivariate approach and sediment quality index evaluation applied to Baixada Santista. Southeastern Brazil. Mar Pollut Bull 143. 7280. https://doi.org/10.1016/j.marpolbul.2019.04.040

Liu M, Zhang A, Liao Y, Chen B, Fan D (2015) The environment quality of heavy metals in sediments from the central Bohai Sea. Mar Pollut Bull 100:534-543. https://doi.org/10.1016/j.marpolbul.2015.09.001

Luiz-Silva W, Matos RHT, Kristosch GC, Machado W (2002) Geochemistry and index of geoaccumulation of Mercury in surface sediments from Santos-Cubatão Estuary. State of São Paulo. Brazil. Quim Nova 25(5):53756. http://doi.org/10.1590/S0100-40422002000500009

Luiz-Silva W, Machado W, Matos RH (2008) Multi-elemental contamination and historic record in sediments from the Santos-Cubatão estuarine system. Brazil. J Braz Chem Soc 19(8)-1490-1500. http://doi.org/10.1590/S0103-50532008000800008

Machado AAS, Spencer K, Kloas W, Toffolon M, Zarf C (2016) Metal fate and effects in estuaries: A review and conceptual model for better understanding of toxicity. Sci Tot Environ 541:268-281.

Manju MN, Kumar CSR, Resmi P, Gireeshkumar TR, Joseph MM, Salas PM, Chandramohanakumar N (2020) Trace metal distribution in the sediment cores of mangrove ecosystems along northern Kerala coast. southwest coast of India. Mar Pollut Bull 153. 110946. https://doi.org/10.1016/j.marpolbul.2020.110946

Martins CC, Mahiques MM, Bícego MC, Fukumoto MM, Montone RC (2007) Comparison betweeen anhtropogenic hydrocarbons and magnetic susceptibility in sediment cores from the Santos Estuary. Brazil. Mar Pollut Bull 54:226-246.

Martins CC, Bícego MC, Mahiques MM, Figueira RCL, Tessler MG, Montone RC (2010) Depositional history of sedimentary linear alkylbenzenes (LABs) in a large South American industrial coastal area (Santos Estuary. Southeastern Brazil). Environ. Pollut. 158(11):3355-3364. http://doi.org/10.1016/j.envpol.2010.07.040

Mirlean N, Roisenberg A (2006) The effect of emissions of fertilizer production on the environment contamination by cadmium and arsenic in southern Brazil. Environ Pollut 143:335-340. doi:10.1016/j.envpol.2005.11.022

Mirlean N, Medeanic S, Garcia FA, Travassos MP, Baisch P (2012) Arsenic enrichment in shelf and coastal sediments of the Brazilian subtropics. Cont Shelf Res 35:129-136. doi:10.1016/j.csr.2012.01.006

Oliveira SMB, Silva PSC, Mazzilli BP, Favaro DIT, Saueia CH (2007) Rare Earth elements as tracers of sediment contamination by phosphogypsum in the Santos estuary. southern Brazil. Appl Geochem 22:837850. doi:10.1016/j.apgeochem.2006.12.017

Ontiveros-Cuadras JF, Ruiz-Fernández AN, Pérez-Bernal LH, de la Peña JL, Sanchez-Cabeza JA (2019) Recent trace metal enrichment and sediment quality assessment in an anthropized coastal lagoon (SE Gulf of California) from 210Pb-dated sediment cores. Mar Pollut Bull. 149:110653. https://doi.org/10.1016/j.marpolbul.2019.11065

Perrota MM, Salvador ED, Lopes RC, D’Agostino LZ, Perrufo N, Gomes SD, Sachs LLD, Meira VT, Lacerda JV (2005) Mapa geológico do estado de São Paulo (Geologic map of the state of São Paulo). scale 1: 750.000. CPRM. São Paulo.

Ramesh R, Chen Z, Cummins V et al. (2015) Land-Ocean Interactions in the Coastal Zone: Past. present and future. Anthropocene. 12, 85-98. https://doi.org/10.1016/j.ancene.2016.01.005

Reimann C, Matschullat J, Birke M, Salminen R (2009) Arsenic distribution in the environment: the effects of scale. App Geochem 24:1147-1167. https ://doi.org/10.1016/j.apgeo chem.2009.03.013

Rubio B, Nombela MA, Vilas F (2000) Geochemistry of major and trace elements in sediments of the Ria de Vigo (NW Spain): an assessment of metal pollution. Mar Pollut Bull 40(11):968-980. https ://doi.org/10.1016/S0025 -326X(00)00039 -4. 
Sá F, Sanders CJ, Patchineelam SR, Machado EV, Lombardi AT (2015) Arsenic fractionation in estuarine sediments: Does coastal eutrophication influence As behavior? Mar. Pollut. Bull. 96:496-501.

Salaroli AB, Kim BSM, Angeli JLF, Figueira RCL (2018) Trace elements in an adjacent channel of an anthropized area: a case study of Baixada Santista. Southeastern Brazil. Ecotoxicol Environ Contam. 13(1):2331.

Silva PSC, Damatto SR, Maldonado C, Fávaro DIT, Mazzilli BP (2011) Metal distribution in sediment cores form São Paulo State coast. Brazil. Mar Pollut Bull 62:1130-1139. doi:10.1016/j.marpolbul.2011.02.046

Steffen W, Crutzen PJ, McNeill JR (2007). The Anthropocene: Are human now overwhelming the great forces of nature? Ambio 36:614-621

Tessler MG, Figueira RCL, Mahiques MM, Fukumoto MM, Ciapina EMP (2006) Sedimentation rates and contamination levels by heavy metals at the shallow sedimentary columns from Santos estuary and bay. SP. Brazil. J Coast Res 39:713-717

Torres RJ, Abessa DMS, Santos FC, Maranho LA, Davanso MB, Nascimento MRL, Mozeto AA (2009) Effects of dredging operations on sediment quality: contaminant mobilization in dredged sediments from the Porto of Santos. J Soil Sed 9:420-432.

Tramonte KM, Figueira RCL, Ferreira PAL, Ribeiro AP, Batista MF, Mahiques MM (2016) Environmental availability of potentially toxic elements in estuarine sediments of the Cananéia-Iguape coastal system. Southeastern Brazil. Mar. Pollut. Bull. 103:250-269. http://dx.doi.org/10.1016/j.marpolbul.2015.12.011

Tramonte KM, Figueira RCL, Majer AP, Ferreira PAL, Batista MF, Ribeiro AP, Mahiques MM (2018) Geochemical behavior, environmental availability. and reconstruction of historical trends of $\mathrm{Cu} . \mathrm{Pb}$. and $\mathrm{Zn}$ in sediment cores of the Cananéia-Iguape coastal system. Southeastern Brazil. Mar Pollut Bull 127:1-9. https://doi.org/10.1016/j.marpolbul.2017.11.016

Turner A (2010) Marine pollution from antifouling paint particles. Mar Pollut Bull 60:159-171. doi: $\underline{10.1016 / \text { j.marpolbul.2009.12.004 }}$

Turney CSM, Palmer J, Maslin MA et al. (2018) Global peak in atmospheric radiocarbon provides a potential definition for the onset of the Anthropocene Epoch in 1965. Scientific Reports, 8, 3293. DOI:10.1038/s41598018-20970-5

UNEP (United Nations Environment Programme) (1995) Manual for the geochemical analyses of marine sediments and suspended particulate matter. Reference Methods for Marine Pollution Studies No. 63 (February).

USEPA (United States Environmental Protection Agency) (1996) Method 3050B. Acid digestion of sediments. sludges and soil. Revision 2. https://www.epa.gov/sites/production/files/2015-06/documents/epa-3050b.pdf Accessed 18 October 2018

Varol M, Canpolat O, Eris KK, Çaglar M (2020) Trace metal in core sediments from a deep lake in eastern Turkey: Vertical concentration profiles. eco-environmental risks and possible sources. Ecotox Environ Safe 189:110060. https://doi.org/10.1016/j.ecoenv.2019.110060

Xavier DA, Santos VF, Miranda AGO, Barrêdo JF (2020) Determination of background geochemistry of an Amazon estuary: The Cuñani Estuary - Amapá. Mar Pollut Bull 155:111144. https://doi.org/10.1016/j.marpolbul.2020.111144

Waters CN, Zalasiewicz J, Summerhayes C et al. (2016). The Anthropocene is functionally and stratigraphically distinct from the Holocene. Science 351 (6269). aad2622. DOI: 10.1126/science.aad2622.

Zalasiewicz J, Waters CN, Williams M et al. (2015) When did the Anthropocene begin? A mid-twentieth century boundary level is stratigraphically optimal. Quat. Int. 383:196-203. 
Zhang J, Liu CL (2002) Riverine composition and estuarine geochemistry of particulate metals in China Weathering features. anthropogenic impact and chemical fluxes. Estuar Coast Shelf Sci 54:1051-1070. $\underline{\text { doi:10.1006/ecss.2001.0879 }}$

Zoller WH, Gladney ES, Duce RA (1974) Atmospheric concentrations and sources of trace metals at the south pole. Science (80-.) 183. 198-200

Zundt C (2006) Baixada Santista: uso. expansão e ocupação do solo. estruturação de rede urbana regional e metropolização. In: Cunha. J. M. P. (Org.). Novas metrópoles paulistas: população. vulnerabilidade e segregação. Campinas. SP: Nepo/Unicamp. p. 305-336. 


\section{List of Figures}
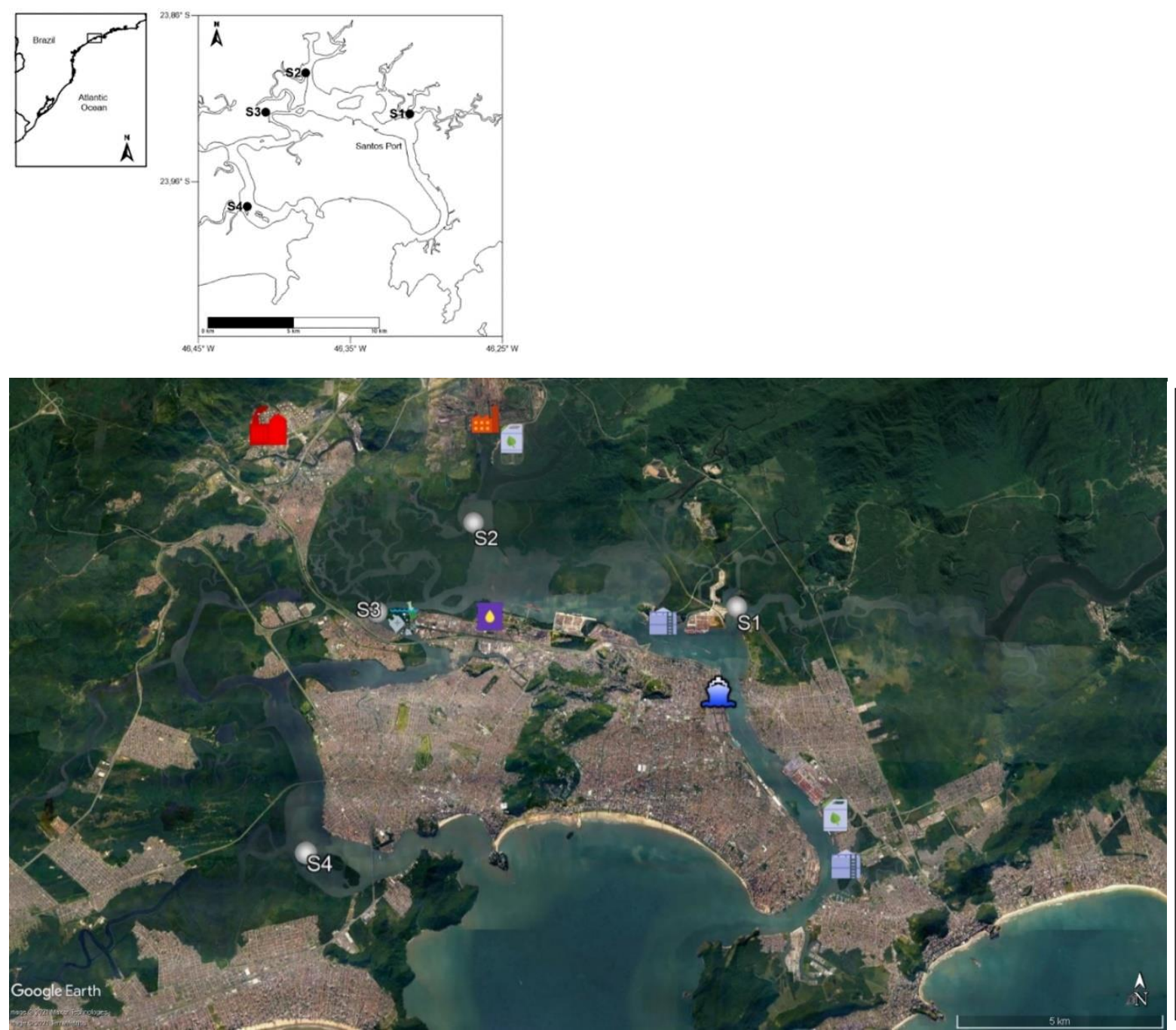

Solid waste disposal

Fig. 1. Sampling locations (S1, S2, S3 and S4) and possible pollution sources along the Santos and São Vicente estuarine system. 


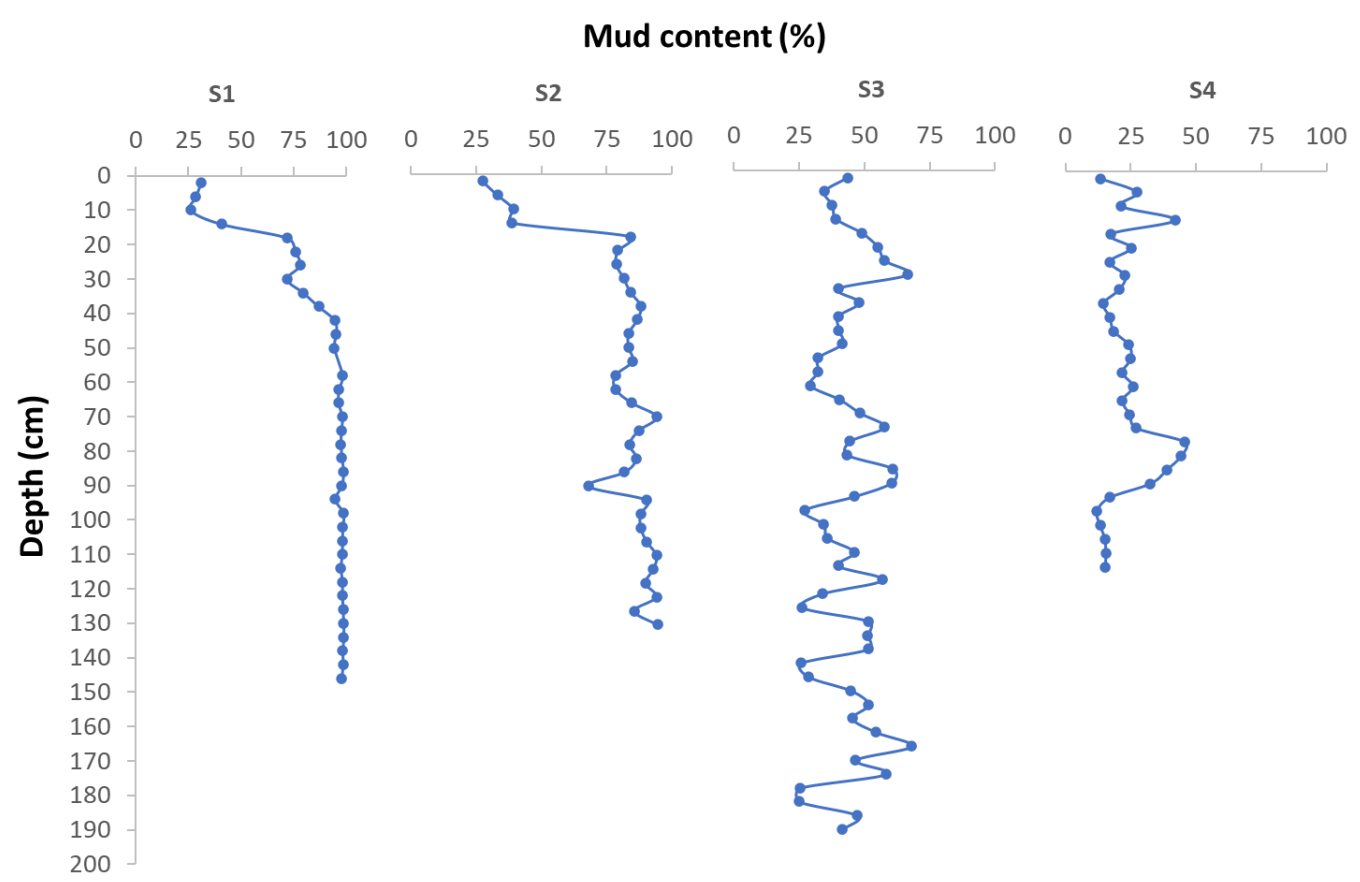

Fig 2. Vertical distribution of Mud content (\%) along with the sediment cores.

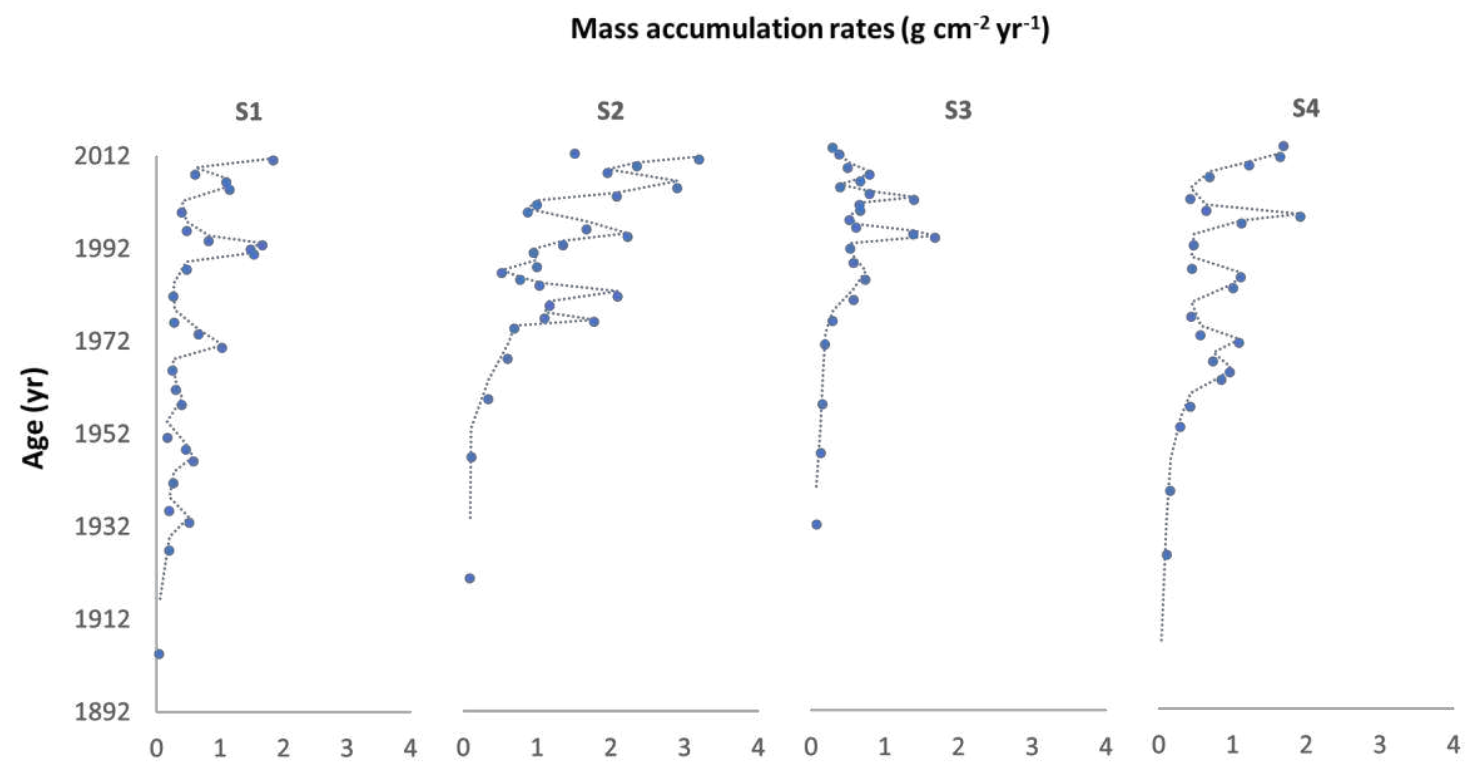

Fig. 3. Mass accumulation rates $\left(\mathrm{g} \mathrm{cm}^{-2} \mathrm{yr}^{-1} v s\right.$ dating of cores from the SSVES. 


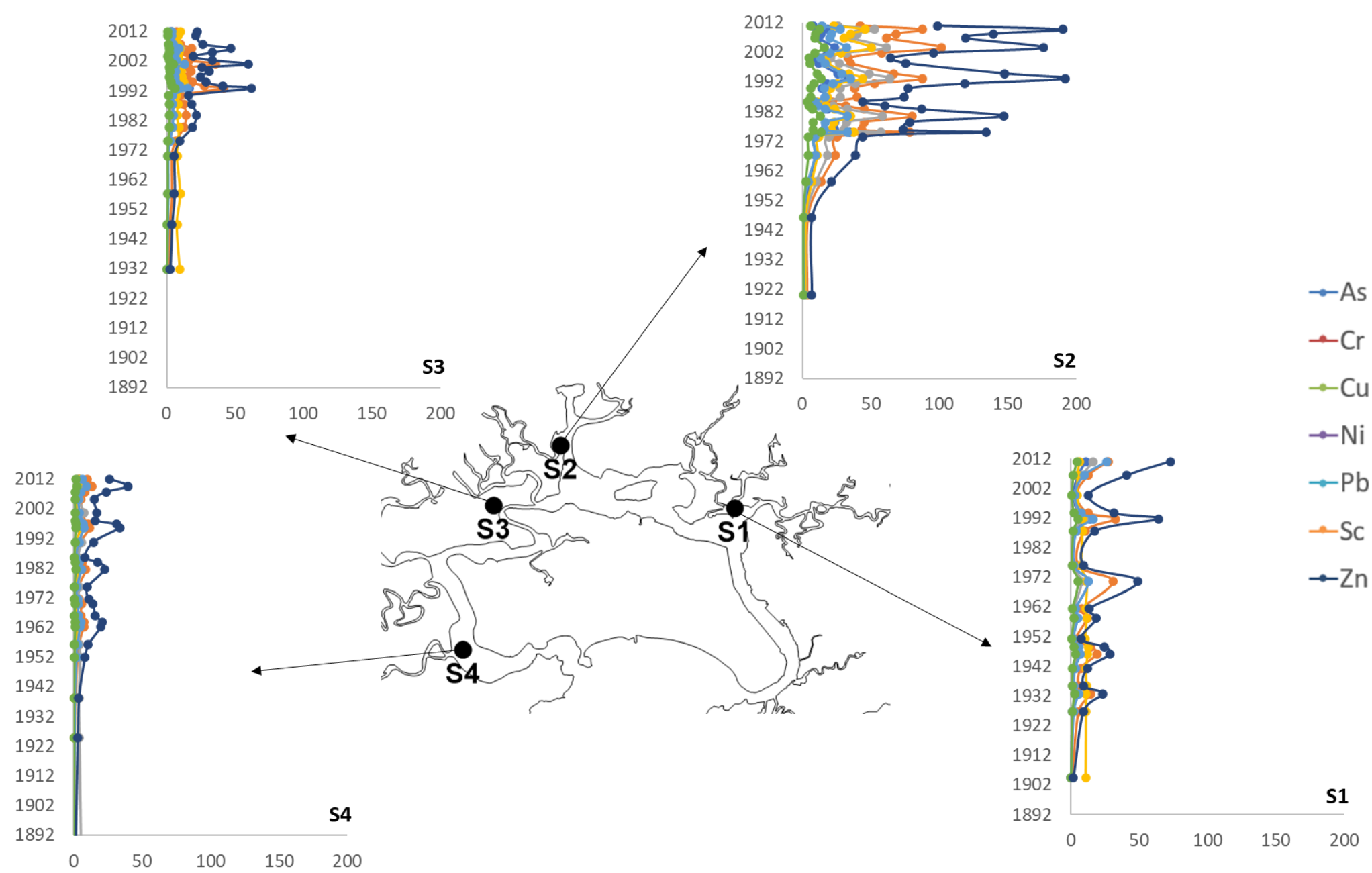

Fig. 4. Trace element fluxes $\left(\mathrm{mg} \mathrm{cm}^{-2} \mathrm{yr}^{-1}\right)$ along the sediment cores of the SSVES. 
S1
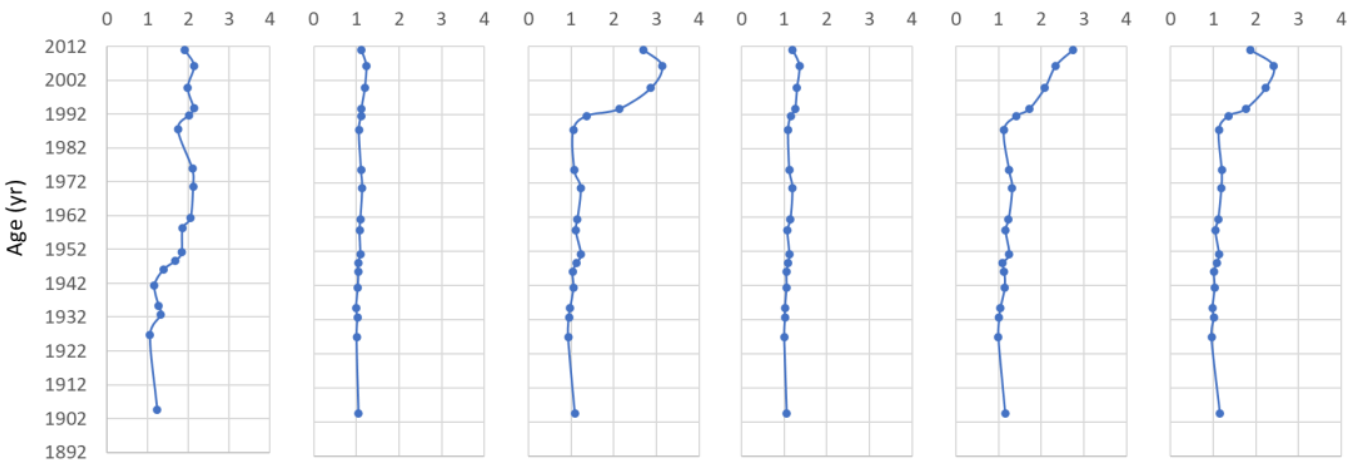

S2

EF Ni

$\mathrm{EF} \mathrm{Pb}$

EF Zn
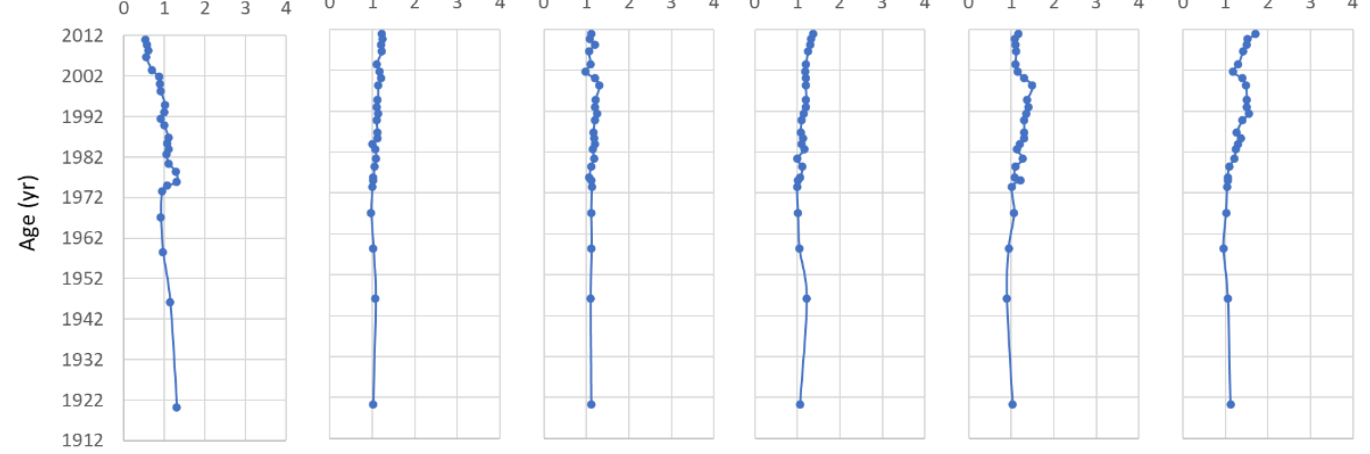

S3

EF As

EF Cu

EF Pb
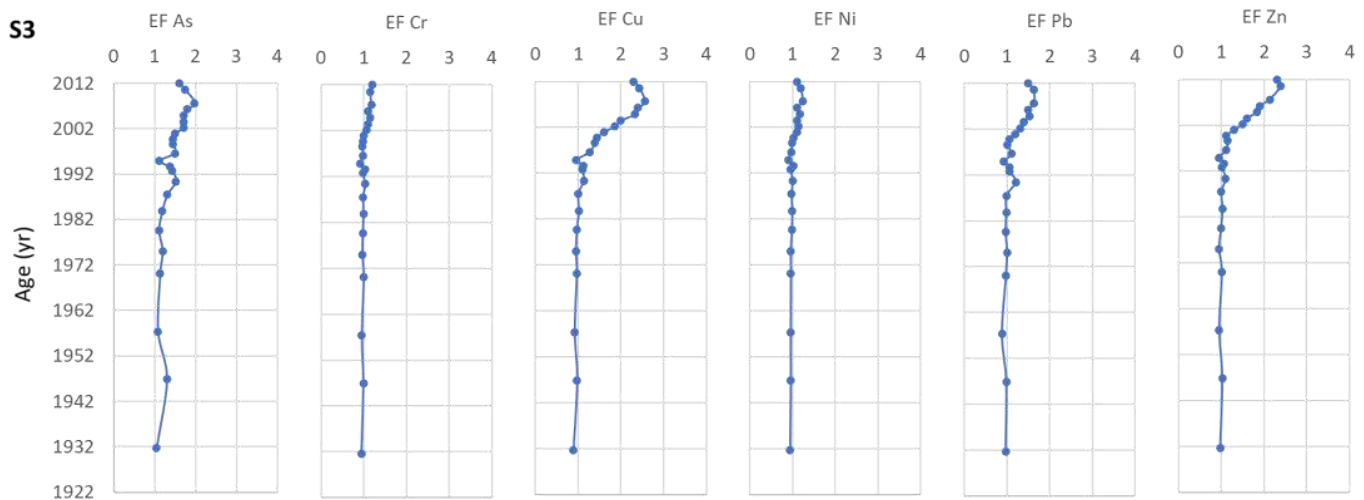

S4

EF Cr

EFCu

EF Ni

EF Pb

EF Zn
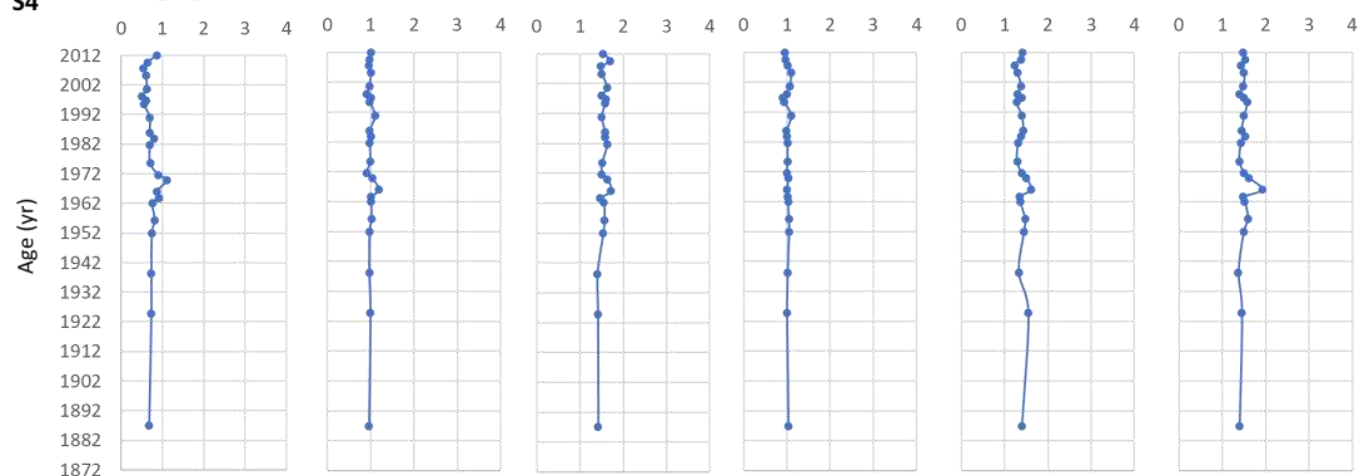

Fig.5. Enrichment Factor (EF) of trace elements from the SSVES sediment cores. 
S1

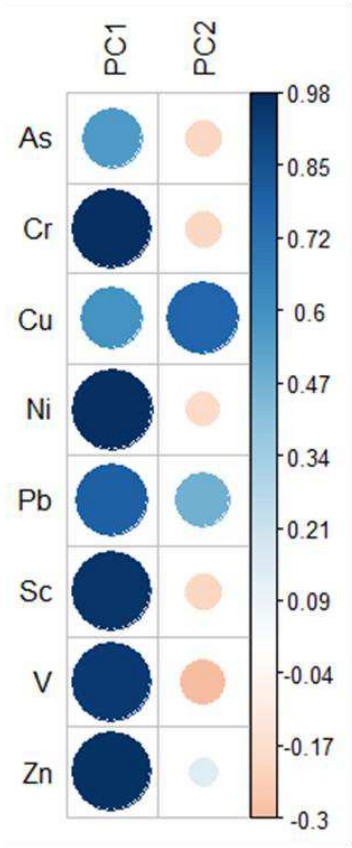

S2

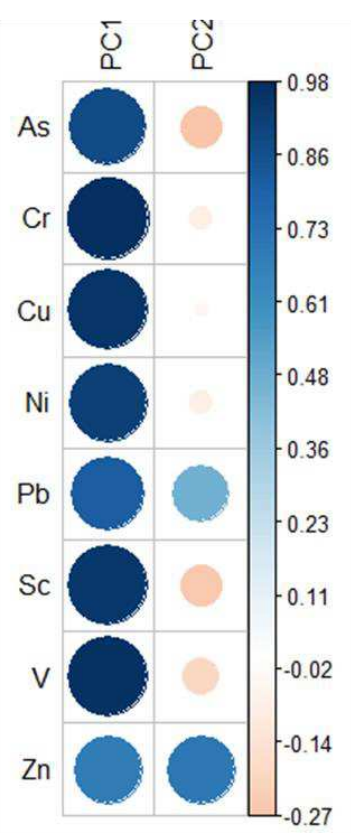

S3

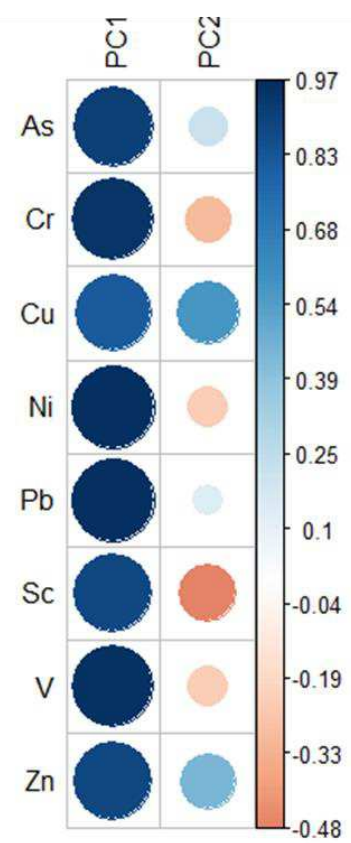

S4

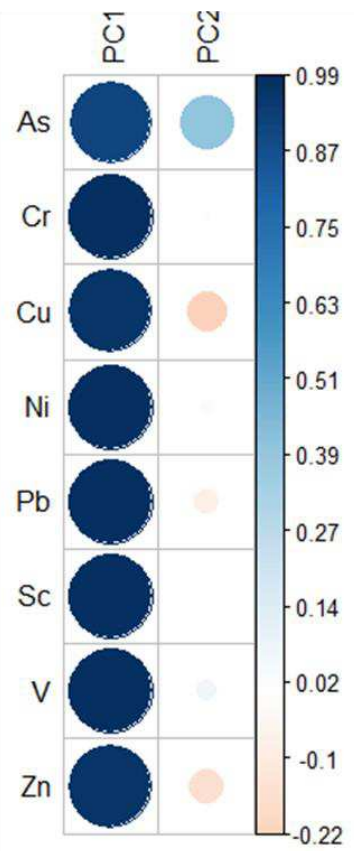

Fig. 6. Loading plots from the PCA of the SSVES sediment cores. 


\section{List of Tables}

Table 1. Confidence interval, mean, relative standard deviation and recovery from the CRM.

\begin{tabular}{|l|l|l|l|l|}
\hline Element & Certified confidence interval $\left.\mathbf{( m g ~} \mathbf{~ k g}^{-1}\right)$ & Mean $\mathbf{( m g ~} \mathbf{~ k g}^{-1}$ ) & Relative standard deviation (\%) & Recovery (\%) \\
\hline $\mathrm{As}$ & $65-85$ & 76.4 & 6 & 101.88 \\
\hline $\mathrm{Cr}$ & $30-38$ & 32.5 & 3 & 95.58 \\
\hline $\mathrm{Cu}$ & $182-200$ & 188.9 & 3 & 98.92 \\
\hline $\mathrm{Ni}$ & $50-58$ & 54.4 & 2 & 100.85 \\
\hline $\mathrm{Pb}$ & $116-136$ & 125.7 & 3 & 99.83 \\
\hline $\mathrm{V}$ & $31-37$ & 29.9 & 4 & 87.91 \\
\hline $\mathrm{Zn}$ & $444-490$ & 467.4 & 4 & 100.09 \\
\hline
\end{tabular}


Table 2. Mean \pm standard deviation, range of concentration and background levels (BL) $\left(\mathrm{mg} \mathrm{kg}^{-1}\right)$ for trace elements from this study, range of concentrations from other studies in the same region and threshold effect and probable effect levels from the Brazilian legislation (CONAMA 454/2012).

\begin{tabular}{|c|c|c|c|c|c|c|c|c|c|}
\hline Location & As & $\mathrm{Cr}$ & $\mathrm{Cu}$ & $\mathbf{N i}$ & $\mathrm{Pb}$ & Sc & $\mathbf{v}$ & $\mathrm{Zn}$ & Reference \\
\hline S1 & $\begin{array}{l}8.94 \pm 2.33 \\
(4.33-13.40) \\
B L=7.31 \pm 2.33\end{array}$ & $\begin{array}{l}27.12 \pm 6.04 \\
(11.05-34.68) \\
B L=31.15 \pm 6.04\end{array}$ & $\begin{array}{l}7.43 \pm 0.90 \\
(4.83-9.44) \\
B L=7.85 \pm 0.90\end{array}$ & $\begin{array}{l}10.62 \pm 2.19 \\
(4.64-13.49) \\
B L=11.93 \pm 2.19\end{array}$ & $\begin{array}{l}11.72 \pm 1.51 \\
(7.56-14.43) \\
B L=12.22 \pm 1.51\end{array}$ & $\begin{array}{l}4.85 \pm 1.22 \\
(1.73-5.73) \\
B L=5.81 \pm 1.22\end{array}$ & $\begin{array}{l}28.21 \pm 5.73 \\
(13.11-36.72) \\
B L=32.06 \pm 5.73\end{array}$ & $\begin{array}{l}45.35 \pm 5.02 \\
(32.94-53.17) \\
B L=49.68 \pm 5.02\end{array}$ & This study \\
\hline S2 & $\begin{array}{l}16.45 \pm 4.81 \\
(5.29-23.66) \\
B L=19.22 \pm 2.42\end{array}$ & $\begin{array}{l}39.93 \pm 5.33 \\
(27.97-50.50) \\
\mathrm{BL}=45.66 \pm 3.23\end{array}$ & $\begin{array}{l}28.19 \pm 4.65 \\
(15.56-33.65) \\
B L=30.76 \pm 2.02\end{array}$ & $\begin{array}{l}19.57 \pm 2.78 \\
(13.48-26.07) \\
B L=21.79 \pm 2.58\end{array}$ & $\begin{array}{l}14.49 \pm 2.66 \\
(8.96-18.64) \\
B L=16.17 \pm 0.67\end{array}$ & $\begin{array}{l}6.77 \pm 1.20 \\
(4.09-8.81) \\
B L=8.09 \pm 0.51\end{array}$ & $\begin{array}{l}50.50 \pm 8.91 \\
(29.54-63.36) \\
B L=59.98 \pm 2.84\end{array}$ & $\begin{array}{l}70.45 \pm 9.92 \\
(46.05-88.19) \\
\mathrm{BL}=75.73 \pm 3.86\end{array}$ & This study \\
\hline S3 & $\begin{array}{l}7.27 \pm 1.94 \\
(2.58-12.20) \\
B L=5.16 \pm 1.74\end{array}$ & $\begin{array}{l}21.65 \pm 4.20 \\
(10.81-31.24) \\
B L=18.39 \pm 6.28\end{array}$ & $\begin{array}{l}5.76 \pm 2.02 \\
(2.64-12.69) \\
B L=4.42 \pm 1.37\end{array}$ & $\begin{array}{l}8.60 \pm 1.62 \\
(4.28-12.19) \\
B L=7.30 \pm 2.39\end{array}$ & $\begin{array}{l}7.86 \pm 1.72 \\
(3.70-12.13) \\
B L=6.33 \pm 2.22\end{array}$ & $\begin{array}{l}3.03 \pm 0.67 \\
(1.44-4.75) \\
B L=2.56 \pm 0.95\end{array}$ & $\begin{array}{l}23.56 \pm 4.88 \\
(11.42-34.22) \\
B L=19.57 \pm 6.87\end{array}$ & $\begin{array}{l}34.22 \pm 10.06 \\
(15.24-75.81) \\
B L=26.84 \pm 9.37\end{array}$ & This study \\
\hline S4 & $\begin{array}{l}3.16 \pm 0.91 \\
(1.48-6.02) \\
B L=2.81 \pm 0.21\end{array}$ & $\begin{array}{l}8.51 \pm 2.91 \\
(5.42-18.09) \\
B L=5.98 \pm 0.61\end{array}$ & $\begin{array}{l}3.83 \pm 1.57 \\
(1.65-8.13) \\
B L=1.830 .18\end{array}$ & $\begin{array}{l}3.62 \pm 1.39 \\
(2.17-8.06) \\
B L=2.47 \pm 0.25\end{array}$ & $\begin{array}{l}5.64 \pm 2.38) \\
2.58-12.65 \\
B L=2.87 \pm 0.26\end{array}$ & $\begin{array}{l}1.29 \pm 0.47 \\
(0.78-2.84) \\
B L=0.90 \pm 0.09\end{array}$ & $\begin{array}{l}10.05 \pm 3.25 \\
(6.51-20.63) \\
B L=7.87 \pm 0.76\end{array}$ & $\begin{array}{l}23.16 \pm 9.33 \\
(9.52-48.35) \\
B L=11.03 \pm 1.31\end{array}$ & This study \\
\hline SSVES. Brazil & $0.70-11.51$ & $3.93-44.78$ & $1.26-48.78$ & $1.67-17.12$ & $2.30-64.02$ & $0.63-5.90$ & $4.61-36.62$ & $10.04-912.56$ & Kim et al. 2018 \\
\hline $\begin{array}{l}\text { Paranaguá Bay, } \\
\text { Brazil }\end{array}$ & $0.13-32.33$ & $0.74-43.75$ & $010-16.54$ & $0.20-16.63$ & $0.39-18.77$ & n.d & n.d & $2.04-66.01$ & Angeli et al. 2020 \\
\hline $\begin{array}{l}\text { Guanabara Bay, } \\
\text { Brazil }\end{array}$ & n.d & $18-297$ & $18-423$ & $11-41$ & $18-287$ & n.d & n.d & $23-698$ & Aguiar et al. 2016 \\
\hline $\begin{array}{l}\text { Caravelas } \\
\text { Estuary,Brazil }\end{array}$ & $2.76-34.24$ & $9.18-62.85$ & $1.40-6.67$ & $1,40-7.37$ & $2.87-23.26$ & n.d & n.d & $10.98-53.29$ & Angeli et al. 2019 \\
\hline $\begin{array}{l}\text { Todos os Santos } \\
\text { Bay, Brazil }\end{array}$ & $0.80-26.3$ & $5.58-17.7$ & $2.52-33.7$ & $1.48-23.7$ & $10.9-325$ & n.d & n.d & $20.1-667$ & $\begin{array}{l}\text { Hatje and Barros, } \\
2012\end{array}$ \\
\hline $\begin{array}{l}\text { Cuñani Estuary, } \\
\text { Brazil }\end{array}$ & $7.10-22.10$ & n.d & $6.00-26.50$ & $12.30-28.50$ & $8.60-27.10$ & $6.00-18.00$ & $54.00-151.00$ & $46.00-93.00$ & Xavier et al. 2020 \\
\hline Level 1 & 19 & 81 & 34 & 20.9 & 46.7 & n.d & n.d & 150 & CONAMA. 2012 \\
\hline Level 2 & 70 & 370 & 270 & 51.6 & 218 & n.d & n.d & 410 & CONAMA. 2012 \\
\hline
\end{tabular}


Supplementary Material

Table S1. Sediment cores information.

\begin{tabular}{|c|c|c|c|}
\hline Sediment core & Latitude & Longitude & Lenght (cm) \\
\hline S1 & $23^{\circ} 55.152^{\prime}$ & $46^{\circ} 18.658^{\prime}$ & 148 \\
\hline S2 & $23^{\circ} 53.670^{\prime}$ & $46^{\circ} 22.765^{\prime}$ & 132 \\
\hline S3 & $23^{\circ} 55.088^{\prime}$ & $46^{\circ} 24.344^{\prime}$ & 192 \\
\hline S4 & $23^{1} 58.493^{\prime}$ & $46^{\circ} 25.069$ & 116 \\
\hline
\end{tabular}

Table S2. Concentrations ( $\mathrm{mg} \mathrm{kg}^{-1}$ ) of trace elements in the sediment core S1 from the SSVES.

\begin{tabular}{|c|c|c|c|c|c|c|c|c|}
\hline S1 & As & $\mathrm{Cr}$ & $\mathrm{Cu}$ & $\mathrm{Ni}$ & $\mathrm{Pb}$ & Sc & V & $\mathrm{Zn}$ \\
\hline 2 & 5.99 & 14.90 & 9.07 & 6.17 & 14.43 & 2.50 & 16.16 & 39.73 \\
\hline 6 & 4.86 & 11.83 & 7.62 & 5.03 & 8.85 & 1.80 & 13.35 & 37.21 \\
\hline 10 & 4.33 & 11.05 & 6.70 & 4.64 & 7.56 & 1.73 & 13.11 & 32.94 \\
\hline 14 & 6.93 & 15.38 & 7.39 & 6.67 & 9.29 & 2.58 & 19.22 & 38.77 \\
\hline 18 & 9.48 & 22.12 & 6.91 & 8.88 & 11.15 & 3.74 & 26.30 & 43.39 \\
\hline 22 & 8.49 & 21.91 & 5.49 & 8.70 & 9.08 & 3.87 & 25.35 & 37.44 \\
\hline 26 & 8.79 & 19.71 & 4.83 & 7.68 & 8.66 & 3.33 & 22.66 & 34.12 \\
\hline 30 & 8.53 & 21.06 & 5.54 & 8.33 & 9.57 & 3.61 & 24.89 & 36.82 \\
\hline 34 & 13.28 & 27.99 & 7.23 & 11.07 & 11.89 & 4.56 & 31.03 & 47.15 \\
\hline 38 & 11.89 & 27.03 & 7.38 & 10.95 & 12.30 & 4.46 & 28.10 & 45.42 \\
\hline 42 & 12.46 & 29.85 & 7.60 & 11.76 & 12.61 & 5.32 & 31.09 & 47.68 \\
\hline 46 & 12.05 & 27.19 & 7.22 & 11.00 & 12.03 & 4.65 & 25.92 & 44.48 \\
\hline 50 & 12.39 & 30.38 & 7.91 & 11.73 & 12.87 & 5.29 & 31.09 & 47.55 \\
\hline 58 & 10.57 & 26.65 & 7.61 & 10.58 & 11.94 & 4.57 & 25.58 & 44.45 \\
\hline 62 & 12.04 & 31.58 & 8.70 & 12.86 & 13.02 & 5.69 & 34.14 & 53.10 \\
\hline 66 & 12.78 & 32.40 & 8.51 & 12.68 & 12.54 & 5.87 & 34.45 & 49.60 \\
\hline 70 & 13.40 & 34.68 & 9.44 & 13.49 & 13.22 & 6.20 & 35.56 & 53.17 \\
\hline 74 & 9.88 & 25.89 & 7.37 & 10.63 & 12.34 & 4.48 & 24.37 & 42.83 \\
\hline 78 & 9.21 & 29.56 & 7.38 & 11.45 & 12.52 & 5.28 & 29.41 & 45.91 \\
\hline 82 & 9.64 & 33.13 & 7.80 & 12.48 & 12.33 & 6.30 & 35.64 & 49.83 \\
\hline 86 & 8.11 & 29.40 & 7.42 & 11.35 & 12.52 & 5.25 & 27.92 & 46.42 \\
\hline 90 & 7.55 & 28.53 & 7.36 & 11.21 & 12.35 & 5.17 & 26.35 & 45.67 \\
\hline 94 & 7.98 & 29.35 & 7.58 & 11.30 & 13.78 & 5.20 & 28.56 & 47.31 \\
\hline 98 & 8.81 & 32.22 & 7.93 & 12.30 & 12.72 & 5.79 & 32.05 & 49.59 \\
\hline 102 & 8.72 & 29.05 & 7.22 & 11.46 & 11.88 & 5.47 & 28.27 & 45.87 \\
\hline 106 & 8.29 & 29.11 & 7.46 & 11.08 & 11.60 & 5.31 & 29.76 & 45.92 \\
\hline 110 & 8.80 & 28.86 & 6.73 & 11.05 & 11.21 & 5.27 & 30.38 & 45.71 \\
\hline 114 & 7.53 & 28.42 & 6.58 & 10.84 & 10.38 & 5.21 & 31.00 & 44.39 \\
\hline 118 & 7.61 & 30.88 & 7.22 & 11.86 & 11.94 & 5.75 & 32.17 & 47.15 \\
\hline 122 & 6.84 & 29.56 & 7.10 & 11.23 & 11.85 & 5.55 & 29.72 & 46.78 \\
\hline 126 & 7.97 & 31.08 & 8.09 & 12.04 & 12.30 & 5.79 & 31.72 & 47.85 \\
\hline
\end{tabular}




\begin{tabular}{|l|l|l|l|l|l|l|l|l|}
$\mathbf{1 3 0}$ & 7.75 & 28.12 & 7.34 & 10.91 & 12.07 & 5.00 & 27.49 & 49.52 \\
\hline $\mathbf{1 3 4}$ & 6.53 & 30.55 & 7.79 & 11.68 & 11.45 & 5.84 & 31.76 & 48.90 \\
\hline $\mathbf{1 3 8}$ & 6.86 & 32.69 & 8.33 & 12.61 & 13.20 & 6.12 & 33.43 & 50.19 \\
\hline $\mathbf{1 4 2}$ & 8.13 & 33.45 & 7.82 & 12.65 & 12.18 & 6.30 & 36.72 & 51.96 \\
\hline $\mathbf{1 4 6}$ & 7.29 & 30.91 & 7.96 & 11.81 & 12.20 & 5.81 & 30.89 & 47.82 \\
\hline
\end{tabular}

Table S3. Concentrations $\left(\mathrm{mg} \mathrm{kg}^{-1}\right)$ of trace elements in the sediment core S2 from the SSVES.

\begin{tabular}{|c|c|c|c|c|c|c|c|c|}
\hline S2 & As & $\mathrm{Cr}$ & $\mathrm{Cu}$ & $\mathrm{Ni}$ & $\mathrm{Pb}$ & Sc & V & $\mathrm{Zn}$ \\
\hline 2 & 5.29 & 28.14 & 17.29 & 15.14 & 9.48 & 4.09 & 29.54 & 65.42 \\
\hline 6 & 5.70 & 29.04 & 17.01 & 14.89 & 8.96 & 4.16 & 30.01 & 59.31 \\
\hline 10 & 6.08 & 31.53 & 18.53 & 15.48 & 10.20 & 4.59 & 33.07 & 60.92 \\
\hline 14 & 8.79 & 27.97 & 15.56 & 13.48 & 9.65 & 4.21 & 31.67 & 46.05 \\
\hline 18 & 13.63 & 40.11 & 31.13 & 20.09 & 18.64 & 6.25 & 48.63 & 86.42 \\
\hline 22 & 15.27 & 39.93 & 28.89 & 20.41 & 17.23 & 6.28 & 47.78 & 88.19 \\
\hline 26 & 13.17 & 38.73 & 28.66 & 18.76 & 16.32 & 6.03 & 45.91 & 87.22 \\
\hline 30 & 16.54 & 39.82 & 27.90 & 18.47 & 16.39 & 6.32 & 49.24 & 74.97 \\
\hline 34 & 16.85 & 41.78 & 29.66 & 20.30 & 17.12 & 6.63 & 51.65 & 84.44 \\
\hline 38 & 17.89 & 43.29 & 31.44 & 22.54 & 16.07 & 7.16 & 54.04 & 83.71 \\
\hline 42 & 16.39 & 38.11 & 27.87 & 16.70 & 15.76 & 6.23 & 47.97 & 70.11 \\
\hline 46 & 20.02 & 38.74 & 27.67 & 19.70 & 14.34 & 6.57 & 49.64 & 67.03 \\
\hline 50 & 21.11 & 39.12 & 27.63 & 19.42 & 14.61 & 6.79 & 51.09 & 66.56 \\
\hline 54 & 19.44 & 44.13 & 32.38 & 21.00 & 18.53 & 7.65 & 57.98 & 75.56 \\
\hline 58 & 14.61 & 36.75 & 27.93 & 17.42 & 13.14 & 6.53 & 48.14 & 63.59 \\
\hline 62 & 18.45 & 35.67 & 25.95 & 16.80 & 14.46 & 6.08 & 46.32 & 62.55 \\
\hline 66 & 15.60 & 39.60 & 30.81 & 21.45 & 11.49 & 6.99 & 50.60 & 66.34 \\
\hline 70 & 16.08 & 40.34 & 31.22 & 20.04 & 15.64 & 7.35 & 53.26 & 69.85 \\
\hline 74 & 14.84 & 40.05 & 30.30 & 18.32 & 13.83 & 7.13 & 51.81 & 63.69 \\
\hline 78 & 15.71 & 42.49 & 30.50 & 21.19 & 12.68 & 7.29 & 53.48 & 64.44 \\
\hline 82 & 16.12 & 40.30 & 29.77 & 19.71 & 13.01 & 6.97 & 51.99 & 62.47 \\
\hline 86 & 11.22 & 33.25 & 24.51 & 14.67 & 11.36 & 5.95 & 43.44 & 50.15 \\
\hline 90 & 17.43 & 38.79 & 26.89 & 20.97 & 11.49 & 6.40 & 48.70 & 63.53 \\
\hline 94 & 23.66 & 44.01 & 30.59 & 23.06 & 13.93 & 7.69 & 57.03 & 69.54 \\
\hline 98 & 21.64 & 44.10 & 31.13 & 21.19 & 13.40 & 7.56 & 56.71 & 67.81 \\
\hline 102 & 22.72 & 41.77 & 30.95 & 20.82 & 14.98 & 7.29 & 53.90 & 76.25 \\
\hline 106 & 21.07 & 45.53 & 30.98 & 21.62 & 17.56 & 8.09 & 60.08 & 75.35 \\
\hline 110 & 21.54 & 46.40 & 33.42 & 23.06 & 17.03 & 8.54 & 62.74 & 74.67 \\
\hline 114 & 19.30 & 42.11 & 28.31 & 20.05 & 16.83 & 7.53 & 55.73 & 76.59 \\
\hline 118 & 20.10 & 45.54 & 30.32 & 21.88 & 16.40 & 7.92 & 59.80 & 73.87 \\
\hline 122 & 20.86 & 46.66 & 31.72 & 21.45 & 16.60 & 8.81 & 61.71 & 75.05 \\
\hline 126 & 20.81 & 50.50 & 33.65 & 26.07 & 15.15 & 8.41 & 63.36 & 81.73 \\
\hline 130 & 15.05 & 43.49 & 29.81 & 19.52 & 15.89 & 7.79 & 59.31 & 71.39 \\
\hline
\end{tabular}


Table S4. Concentrations ( $\mathrm{mg} \mathrm{kg}^{-1}$ ) of trace elements in the sediment core S3 from the SSVES.

\begin{tabular}{|c|c|c|c|c|c|c|c|c|}
\hline S3 & As & $\mathrm{Cr}$ & $\mathrm{Cu}$ & $\mathrm{Ni}$ & $\mathrm{Pb}$ & Sc & v & $\mathrm{Zn}$ \\
\hline 2 & 10.60 & 25.06 & 12.69 & 10.30 & 12.13 & 3.02 & 26.05 & 75.81 \\
\hline 6 & 9.48 & 20.17 & 10.49 & 8.40 & 9.61 & 2.37 & 22.71 & 53.22 \\
\hline 10 & 8.90 & 21.27 & 10.45 & 8.66 & 9.82 & 2.59 & 23.56 & 49.96 \\
\hline 14 & 9.33 & 20.55 & 8.63 & 8.71 & 8.78 & 2.69 & 25.58 & 42.16 \\
\hline 18 & 9.90 & 24.02 & 8.44 & 9.87 & 8.86 & 3.40 & 30.51 & 39.85 \\
\hline 22 & 11.24 & 26.76 & 9.27 & 10.84 & 9.62 & 3.84 & 32.77 & 46.45 \\
\hline 26 & 12.20 & 28.35 & 8.81 & 11.15 & 11.10 & 4.04 & 33.29 & 47.08 \\
\hline 30 & 10.64 & 31.24 & 7.83 & 12.19 & 10.91 & 4.75 & 34.22 & 47.02 \\
\hline 34 & 7.39 & 19.85 & 5.16 & 7.71 & 7.01 & 2.66 & 21.73 & 29.50 \\
\hline 38 & 9.95 & 24.59 & 6.58 & 9.46 & 9.15 & 3.47 & 26.53 & 36.91 \\
\hline 42 & 7.94 & 19.19 & 5.04 & 7.39 & 7.72 & 2.58 & 20.65 & 29.85 \\
\hline 46 & 7.91 & 21.28 & 5.17 & 8.33 & 7.32 & 2.99 & 24.05 & 31.39 \\
\hline 50 & 6.53 & 19.55 & 4.78 & 7.73 & 6.68 & 2.73 & 21.11 & 29.37 \\
\hline 54 & 6.91 & 21.80 & 5.18 & 8.70 & 7.48 & 3.10 & 24.99 & 32.36 \\
\hline 58 & 7.92 & 22.94 & 5.37 & 8.98 & 8.16 & 3.29 & 25.06 & 32.56 \\
\hline 62 & 6.38 & 20.09 & 4.66 & 7.64 & 6.75 & 2.79 & 23.14 & 29.57 \\
\hline 66 & 6.16 & 20.03 & 4.76 & 8.03 & 6.94 & 2.86 & 22.33 & 29.65 \\
\hline 70 & 7.98 & 25.15 & 5.80 & 9.96 & 8.02 & 3.66 & 27.89 & 36.43 \\
\hline 74 & 8.22 & 26.34 & 6.27 & 10.51 & 9.28 & 3.82 & 28.38 & 39.24 \\
\hline 78 & 8.25 & 26.31 & 6.05 & 10.10 & 8.75 & 3.73 & 29.43 & 39.08 \\
\hline 82 & 7.31 & 19.89 & 4.71 & 7.63 & 6.81 & 2.79 & 21.74 & 29.89 \\
\hline 86 & 8.85 & 24.99 & 5.78 & 9.92 & 8.23 & 3.62 & 26.38 & 38.59 \\
\hline 90 & 7.63 & 24.53 & 5.55 & 9.71 & 8.69 & 3.61 & 26.52 & 36.81 \\
\hline 94 & 6.31 & 21.58 & 4.97 & 8.40 & 7.59 & 3.08 & 23.28 & 30.66 \\
\hline 98 & 4.69 & 16.33 & 3.81 & 6.48 & 5.23 & 2.33 & 17.66 & 23.73 \\
\hline 102 & 5.94 & 15.72 & 3.57 & 6.47 & 5.52 & 2.24 & 16.45 & 24.38 \\
\hline 106 & 6.21 & 20.47 & 4.47 & 7.91 & 7.54 & 2.82 & 21.14 & 29.50 \\
\hline 110 & 7.69 & 22.13 & 5.12 & 8.51 & 7.83 & 3.07 & 22.15 & 32.79 \\
\hline 114 & 5.67 & 16.66 & 4.13 & 6.98 & 6.26 & 2.29 & 17.31 & 25.17 \\
\hline 118 & 9.16 & 29.52 & 6.84 & 11.41 & 10.89 & 4.36 & 30.24 & 44.31 \\
\hline 122 & 5.85 & 22.26 & 4.90 & 8.78 & 7.94 & 3.27 & 22.72 & 31.19 \\
\hline 126 & 4.11 & 14.58 & 3.34 & 5.71 & 5.04 & 2.02 & 16.32 & 21.26 \\
\hline 130 & 7.03 & 21.39 & 4.98 & 8.46 & 8.04 & 3.04 & 21.50 & 31.85 \\
\hline 134 & 5.33 & 18.52 & 4.33 & 7.95 & 6.94 & 2.60 & 19.63 & 27.85 \\
\hline 138 & 6.19 & 21.82 & 4.93 & 8.65 & 7.75 & 3.14 & 23.63 & 32.06 \\
\hline 142 & 5.69 & 17.13 & 3.98 & 7.19 & 6.49 & 2.40 & 18.28 & 24.90 \\
\hline 146 & 5.24 & 15.30 & 3.57 & 6.03 & 5.30 & 2.01 & 16.72 & 21.51 \\
\hline 150 & 6.09 & 21.63 & 5.22 & 8.90 & 7.76 & 3.04 & 23.01 & 31.05 \\
\hline 154 & 7.91 & 23.14 & 5.57 & 9.09 & 8.65 & 3.08 & 24.23 & 33.58 \\
\hline 158 & 6.94 & 22.81 & 6.10 & 9.02 & 8.53 & 3.17 & 23.66 & 33.69 \\
\hline
\end{tabular}




\begin{tabular}{|r|r|r|r|r|r|r|r|r|}
\hline 162 & 5.75 & 20.37 & 4.80 & 8.12 & 6.92 & 2.87 & 22.00 & 29.84 \\
\hline 166 & 7.43 & 28.53 & 6.64 & 11.28 & 9.73 & 4.21 & 29.82 & 41.71 \\
\hline 170 & 6.45 & 23.30 & 5.41 & 9.17 & 7.76 & 3.34 & 24.84 & 34.45 \\
\hline 174 & 7.38 & 26.79 & 6.21 & 10.39 & 9.19 & 3.87 & 28.66 & 39.38 \\
\hline 178 & 2.58 & 10.81 & 2.64 & 4.28 & 3.70 & 1.44 & 11.42 & 15.24 \\
\hline 182 & 4.75 & 13.76 & 3.57 & 5.67 & 4.51 & 1.89 & 14.22 & 20.31 \\
\hline 186 & 5.64 & 20.96 & 4.93 & 8.44 & 6.99 & 2.96 & 22.64 & 30.32 \\
\hline 190 & 5.43 & 19.64 & 4.73 & 7.71 & 7.28 & 2.62 & 20.91 & 28.94 \\
\hline
\end{tabular}

Table S5. Concentrations $\left(\mathrm{mg} \mathrm{kg}^{-1}\right)$ of trace elements in the sediment core S4 from the SSVES.

\begin{tabular}{|c|c|c|c|c|c|c|c|c|}
\hline S4 & As & $\mathrm{Cr}$ & $\mathrm{Cu}$ & $\mathrm{Ni}$ & $\mathbf{P b}$ & Sc & $\mathbf{V}$ & $\mathrm{Zn}$ \\
\hline 2 & 2.29 & 5.74 & 2.65 & 2.22 & 3.86 & 0.86 & 6.96 & 15.50 \\
\hline 6 & 2.57 & 8.23 & 4.41 & 3.40 & 5.63 & 1.29 & 9.55 & 24.10 \\
\hline 10 & 2.09 & 7.87 & 3.72 & 3.45 & 4.83 & 1.24 & 9.70 & 21.59 \\
\hline 14 & 4.19 & 13.96 & 7.14 & 6.37 & 9.52 & 2.18 & 16.25 & 39.43 \\
\hline 18 & 1.48 & 5.50 & 2.70 & 2.17 & 3.43 & 0.85 & 6.51 & 16.26 \\
\hline 22 & 3.68 & 10.94 & 5.43 & 4.61 & 7.75 & 1.70 & 12.71 & 29.86 \\
\hline 26 & 2.07 & 5.62 & 2.68 & 2.28 & 3.67 & 0.84 & 6.56 & 15.62 \\
\hline 30 & 2.90 & 8.62 & 4.38 & 3.69 & 5.52 & 1.33 & 10.23 & 23.05 \\
\hline 34 & 2.91 & 8.69 & 4.05 & 3.68 & 5.45 & 1.33 & 10.48 & 22.49 \\
\hline 38 & 3.28 & 6.50 & 3.14 & 2.68 & 4.54 & 0.95 & 7.87 & 18.80 \\
\hline 42 & 2.43 & 7.11 & 3.12 & 2.48 & 4.58 & 0.90 & 7.24 & 21.04 \\
\hline 46 & 3.41 & 8.01 & 3.53 & 3.34 & 5.10 & 1.20 & 9.56 & 21.66 \\
\hline 50 & 2.96 & 8.39 & 3.94 & 3.53 & 5.42 & 1.26 & 10.01 & 23.27 \\
\hline 54 & 3.17 & 8.49 & 3.96 & 3.60 & 5.88 & 1.26 & 9.97 & 24.34 \\
\hline 58 & 3.49 & 9.70 & 4.67 & 4.34 & 6.94 & 1.51 & 11.58 & 27.40 \\
\hline 62 & 3.11 & 8.68 & 3.84 & 3.80 & 5.75 & 1.36 & 10.40 & 22.71 \\
\hline 66 & 2.86 & 6.68 & 3.35 & 2.71 & 5.30 & 1.00 & 7.56 & 22.12 \\
\hline 70 & 3.37 & 9.73 & 4.20 & 4.06 & 7.26 & 1.48 & 11.82 & 26.11 \\
\hline 74 & 4.88 & 12.37 & 6.18 & 5.74 & 9.53 & 1.87 & 14.91 & 41.77 \\
\hline 78 & 6.02 & 18.09 & 8.13 & 8.06 & 12.65 & 2.84 & 20.63 & 48.35 \\
\hline 82 & 4.37 & 12.52 & 5.43 & 5.38 & 8.71 & 1.90 & 13.95 & 33.86 \\
\hline 86 & 3.45 & 9.65 & 3.96 & 4.00 & 6.99 & 1.45 & 10.67 & 26.52 \\
\hline 90 & 4.03 & 9.65 & 4.47 & 4.32 & 7.10 & 1.46 & 10.83 & 30.25 \\
\hline 94 & 2.58 & 6.23 & 2.85 & 2.83 & 3.79 & 0.92 & 7.31 & 20.34 \\
\hline 98 & 2.55 & 5.42 & 1.65 & 2.23 & 2.60 & 0.78 & 7.44 & 10.19 \\
\hline 102 & 2.77 & 5.82 & 1.78 & 2.36 & 2.99 & 0.90 & 7.39 & 10.64 \\
\hline 106 & 3.07 & 6.73 & 2.08 & 2.78 & 3.02 & 1.01 & 8.84 & 12.35 \\
\hline 110 & 2.67 & 5.44 & 1.67 & 2.28 & 2.58 & 0.84 & 6.79 & 9.52 \\
\hline 114 & 2.96 & 6.51 & 1.95 & 2.69 & 3.15 & 0.99 & 7.87 & 12.44 \\
\hline
\end{tabular}


Table S6. Analysis data using CRS model and the ${ }^{137} \mathrm{Cs}$ fallout to calculate the age (yr), sediment accumulation rates $\left(\mathrm{cm} \mathrm{yr}^{-1}\right)$ and mass accumulation $\left(\mathrm{g} \mathrm{cm}^{-2} \mathrm{yr}^{-1}\right)$ rates in sediment core $\mathrm{S} 1$.

\begin{tabular}{|c|c|c|c|c|c|c|c|c|}
\hline \multirow{3}{*}{$z(\mathrm{~cm})$} & \multicolumn{6}{|c|}{ CRS } & \multirow{2}{*}{\multicolumn{2}{|c|}{$\begin{array}{c}\text { Fallout } \\
{ }^{137} \mathrm{Cs} \\
\text { Dating (yr) }\end{array}$}} \\
\hline & \multicolumn{2}{|c|}{ Dating (yr) } & \multicolumn{2}{|c|}{$\mathrm{v}\left(\mathrm{cm} \mathrm{yr} \mathrm{r}^{-1}\right)$} & \multicolumn{2}{|c|}{$\mathrm{f}\left(\mathrm{g} \mathrm{cm}^{-2} \mathrm{yr}^{-1}\right)$} & & \\
\hline & Value & Error & Value & Error & Value & Error & Value & Error \\
\hline 0 & 2012 & 0 & & & & & 2012 & 0 \\
\hline 2 & 2011 & 0 & 2.05 & 0.23 & 1.83 & 0.20 & 2009 & 0 \\
\hline 4 & 2008 & 0 & 0.63 & 0.07 & 0.61 & 0.06 & 2007 & 0 \\
\hline 6 & 2006 & 1 & 1.13 & 0.12 & 1.10 & 0.12 & 2004 & 1 \\
\hline 8 & 2005 & 1 & 1.18 & 0.13 & 1.15 & 0.13 & 2001 & 1 \\
\hline 10 & 2000 & 1 & 0.38 & 0.04 & 0.40 & 0.04 & 1998 & 1 \\
\hline 12 & 1996 & 2 & 0.47 & 0.05 & 0.47 & 0.05 & 1996 & 1 \\
\hline 14 & 1994 & 2 & 0.89 & 0.10 & 0.82 & 0.09 & 1993 & 1 \\
\hline 16 & 1993 & 2 & 2.10 & 0.24 & 1.67 & 0.19 & 1990 & 2 \\
\hline 18 & 1992 & 2 & 1.90 & 0.22 & 1.48 & 0.17 & 1988 & 2 \\
\hline 20 & 1991 & 2 & 2.01 & 0.24 & 1.54 & 0.18 & 1985 & 2 \\
\hline 22 & 1987 & 3 & 0.58 & 0.07 & 0.47 & 0.05 & 1982 & 2 \\
\hline 24 & 1982 & 3 & 0.31 & 0.03 & 0.27 & 0.03 & 1979 & 2 \\
\hline 26 & 1976 & 4 & 0.32 & 0.04 & 0.28 & 0.03 & 1977 & 3 \\
\hline 28 & 1973 & 4 & 0.76 & 0.09 & 0.66 & 0.07 & 1974 & 3 \\
\hline 30 & 1973 & 5 & & & & & 1971 & 3 \\
\hline 32 & 1972 & 5 & & & & & 1968 & 3 \\
\hline 34 & 1972 & 5 & & & & & 1966 & 3 \\
\hline 36 & 1972 & 4 & & & & & 1963 & 4 \\
\hline 38 & 1972 & 4 & & & & & 1960 & 4 \\
\hline 40 & 1971 & 5 & 1.50 & 0.17 & 1.03 & 0.12 & 1958 & 4 \\
\hline 44 & 1966 & 5 & 0.37 & 0.04 & 0.25 & 0.03 & 1952 & 5 \\
\hline 48 & 1961 & 5 & 0.44 & 0.05 & 0.30 & 0.03 & 1947 & 5 \\
\hline 52 & 1958 & 6 & 0.60 & 0.07 & 0.40 & 0.04 & 1941 & 6 \\
\hline 56 & 1951 & 7 & 0.25 & 0.03 & 0.17 & 0.02 & 1936 & 6 \\
\hline 60 & 1949 & 7 & 0.74 & 0.08 & 0.46 & 0.05 & 1930 & 6 \\
\hline 70 & 1948 & 7 & & & & & 1917 & 7 \\
\hline 80 & 1946 & 7 & 0.92 & 0.10 & 0.58 & 0.06 & 1903 & 8 \\
\hline 90 & 1941 & 8 & 0.40 & 0.04 & 0.27 & 0.03 & 1890 & 10 \\
\hline 100 & 1935 & 8 & 0.30 & 0.03 & 0.20 & 0.02 & 1876 & 11 \\
\hline 110 & 1933 & 9 & 0.74 & 0.08 & 0.51 & 0.06 & 1862 & 12 \\
\hline 120 & 1927 & 9 & 0.31 & 0.03 & 0.20 & 0.02 & 1849 & 12 \\
\hline 130 & 1905 & 11 & 0.06 & 0.01 & 0.04 & 0.00 & 1835 & 14 \\
\hline
\end{tabular}


Table S7. Analysis data using CRS model and the ${ }^{137} \mathrm{Cs}$ fallout to calculate the age (yr), sediment accumulation rates $\left(\mathrm{cm} \mathrm{yr}^{-1}\right)$ and mass accumulation $\left(\mathrm{g} \mathrm{cm}^{-2} \mathrm{yr}^{-1}\right)$ rates in sediment core $\mathrm{S2}$.

\begin{tabular}{|c|c|c|c|c|c|c|c|c|}
\hline & \multicolumn{9}{|c|}{ CRS } & \multicolumn{2}{c|}{$\begin{array}{c}\text { Fallout } \\
137 \\
\end{array}$} & \multicolumn{7}{|c|}{$\mathrm{Cs}$} \\
\hline $\mathrm{z}(\mathrm{cm})$ & \multicolumn{2}{|c|}{ Dating (yr) } & \multicolumn{2}{c|}{$\mathrm{v}\left(\mathrm{cm} \mathrm{yr}^{-1}\right)$} & \multicolumn{2}{c|}{$\mathrm{f}\left(\mathrm{g} \mathrm{cm}^{-2} \mathrm{yr}^{-1}\right)$} & \multicolumn{2}{|c|}{ Dating (yr) } \\
\cline { 2 - 10 } & Value & Error & Value & Error & Value & Error & Value & Error \\
\hline 2 & 2011 & 0 & 0.80 & 0.06 & 1.51 & 0.11 & 2009 & 0 \\
\hline 4 & 2010 & 0 & 1.69 & 0.13 & 3.19 & 0.24 & 2006 & 0 \\
\hline 6 & 2008 & 0 & 1.25 & 0.11 & 2.35 & 0.21 & 2003 & 0 \\
\hline 8 & 2007 & 1 & 1.07 & 0.08 & 1.96 & 0.14 & 2000 & 0 \\
\hline 12 & 2003 & 1 & 1.69 & 0.13 & 2.90 & 0.23 & 1995 & 0 \\
\hline 14 & 2002 & 1 & 1.25 & 0.10 & 2.08 & 0.16 & 1992 & 0 \\
\hline 16 & 2000 & 1 & 0.68 & 0.06 & 1.00 & 0.09 & 1989 & 1 \\
\hline 18 & 1998 & 2 & 0.81 & 0.08 & 0.87 & 0.09 & 1986 & 1 \\
\hline 22 & 1995 & 1 & 1.44 & 0.13 & 1.67 & 0.15 & 1980 & 1 \\
\hline 24 & 1993 & 1 & 1.96 & 0.17 & 2.23 & 0.19 & 1977 & 1 \\
\hline 26 & 1991 & 2 & 1.14 & 0.11 & 1.36 & 0.13 & 1975 & 1 \\
\hline 28 & 1990 & 2 & 0.76 & 0.07 & 0.95 & 0.08 & 1972 & 1 \\
\hline 32 & 1987 & 2 & 0.80 & 0.07 & 0.99 & 0.08 & 1966 & 1 \\
\hline 34 & 1985 & 3 & 0.46 & 0.05 & 0.52 & 0.05 & 1963 & 1 \\
\hline 36 & 1984 & 4 & 0.61 & 0.07 & 0.77 & 0.09 & 1960 & 2 \\
\hline 38 & 1983 & 3 & 0.84 & 0.09 & 1.04 & 0.11 & 1957 & 1 \\
\hline 42 & 1980 & 3 & 1.77 & 0.16 & 2.10 & 0.18 & 1951 & 1 \\
\hline 46 & 1978 & 3 & 0.99 & 0.09 & 1.17 & 0.10 & 1946 & 2 \\
\hline 52 & 1976 & 3 & 0.91 & 0.07 & 1.11 & 0.08 & 1937 & 2 \\
\hline 54 & 1975 & 3 & 1.52 & 0.13 & 1.77 & 0.15 & 1934 & 2 \\
\hline 58 & 1974 & 4 & 0.51 & 0.04 & 0.69 & 0.06 & 1928 & 2 \\
\hline 72 & 1967 & 4 & 0.48 & 0.04 & 0.60 & 0.05 & 1908 & 2 \\
\hline 82 & 1958 & 4 & 0.25 & 0.02 & 0.34 & 0.03 & 1894 & 3 \\
\hline 90 & 1946 & 6 & 0.08 & 0.01 & 0.11 & 0.01 & 1882 & 3 \\
\hline 100 & 1920 & 7 & 0.07 & 0.01 & 0.09 & 0.01 & 1868 & 3 \\
\hline
\end{tabular}


Table S8. Analysis data using CRS model and the ${ }^{137} \mathrm{Cs}$ fallout to calculate the age (yr), sediment accumulation rates $\left(\mathrm{cm} \mathrm{yr}^{-1}\right)$ and mass accumulation $\left(\mathrm{g} \mathrm{cm}^{-2} \mathrm{yr}^{-1}\right)$ rates in sediment core $\mathrm{S3}$.

\begin{tabular}{|c|c|c|c|c|c|c|c|c|}
\hline & \multicolumn{9}{|c|}{ CRS } & \multicolumn{2}{c|}{$\begin{array}{c}\text { Fallout } \\
137\end{array}$} \\
\hline \multirow{2}{*}{$\mathrm{z}(\mathrm{cm})$} & \multicolumn{2}{|c|}{ Dating (yr) } & \multicolumn{2}{c|}{$\mathrm{v}\left(\mathrm{cm} \mathrm{yr}^{-1}\right)$} & \multicolumn{2}{c|}{$\mathrm{f}\left(\mathrm{g} \mathrm{cm}^{-2} \mathrm{yr}^{-1}\right)$} & \multicolumn{2}{c|}{ Dating (yr) } \\
\cline { 2 - 10 } & Value & Error & Value & Error & Value & Error & Value & Error \\
\hline 0 & 2012 & 1 & 0.52 & 0.07 & 0.30 & 0.04 & 2012 & 0 \\
\hline 2 & 2011 & 2 & 0.63 & 0.17 & 0.38 & 0.10 & 2007 & 0 \\
\hline 6 & 2008 & 1 & 0.85 & 0.10 & 0.50 & 0.06 & 1997 & 0 \\
\hline 8 & 2006 & 1 & 1.42 & 0.17 & 0.80 & 0.10 & 1992 & 0 \\
\hline 10 & 2005 & 1 & 1.42 & 0.16 & 0.66 & 0.07 & 1988 & 1 \\
\hline 12 & 2003 & 1 & 1.43 & 0.15 & 0.39 & 0.04 & 1983 & 1 \\
\hline 14 & 2002 & 1 & 1.49 & 0.14 & 0.79 & 0.08 & 1978 & 1 \\
\hline 16 & 2001 & 2 & 2.56 & 0.27 & 1.40 & 0.15 & 1973 & 1 \\
\hline 18 & 2000 & 2 & 1.13 & 0.11 & 0.65 & 0.06 & 1968 & 1 \\
\hline 20 & 1999 & 2 & 2.40 & 0.31 & 0.66 & 0.09 & 1963 & 1 \\
\hline 24 & 1997 & 2 & 0.89 & 0.11 & 0.52 & 0.06 & 1953 & 1 \\
\hline 28 & 1995 & 2 & 0.92 & 0.10 & 0.61 & 0.07 & 1943 & 2 \\
\hline 32 & 1994 & 3 & 1.60 & 0.17 & 1.38 & 0.15 & 1934 & 2 \\
\hline 36 & 1993 & 2 & 2.11 & 0.22 & 1.68 & 0.18 & 1924 & 2 \\
\hline 40 & 1990 & 3 & 0.69 & 0.07 & 0.53 & 0.06 & 1914 & 2 \\
\hline 44 & 1987 & 3 & 0.68 & 0.07 & 0.58 & 0.06 & 1904 & 3 \\
\hline 48 & 1984 & 3 & 0.80 & 0.08 & 0.74 & 0.07 & 1894 & 3 \\
\hline 52 & 1980 & 4 & 0.72 & 0.07 & 0.58 & 0.06 & 1885 & 3 \\
\hline 56 & 1975 & 4 & 0.33 & 0.03 & 0.29 & 0.03 & 1875 & 3 \\
\hline 60 & 1970 & 4 & 0.20 & 0.02 & 0.19 & 0.02 & 1865 & 4 \\
\hline 70 & 1957 & 6 & 0.20 & 0.02 & 0.16 & 0.02 & 1841 & 4 \\
\hline 80 & 1947 & 6 & 0.14 & 0.01 & 0.13 & 0.01 & 1816 & 5 \\
\hline 90 & 1932 & 9 & 0.10 & 0.01 & 0.07 & 0.01 & 1792 & 5 \\
\hline
\end{tabular}


Table S9. Analysis data using CRS model and the ${ }^{137} \mathrm{Cs}$ fallout to calculate the age (yr), sediment accumulation rates $\left(\mathrm{cm} \mathrm{yr}^{-1}\right)$ and mass accumulation $\left(\mathrm{g} \mathrm{cm}^{-2} \mathrm{yr}^{-1}\right)$ rates in sediment core $S 4$.

\begin{tabular}{|c|c|c|c|c|c|c|c|c|}
\hline \multirow{3}{*}{$\mathrm{z}(\mathrm{cm})$} & \multicolumn{6}{|c|}{ CRS } & \multirow{2}{*}{\multicolumn{2}{|c|}{$\begin{array}{c}\text { Fallout } \\
{ }^{137} \mathrm{Cs} \\
\text { Dating (yr) }\end{array}$}} \\
\hline & \multicolumn{2}{|c|}{ Dating (yr) } & \multicolumn{2}{|c|}{$\mathrm{v}\left(\mathrm{cm} \mathrm{yr}^{-1}\right)$} & \multicolumn{2}{|c|}{$f\left(g \mathrm{~cm}^{-2} \mathrm{yr}^{-1}\right)$} & & \\
\hline & Value & Error & Value & Error & Value & Error & Value & Error \\
\hline 0 & 2012 & 0 & 1.23 & 0.15 & 1.70 & 0.21 & 2012 & 0 \\
\hline 2 & 2012 & 0 & & & & & 2009 & 0 \\
\hline 4 & 2011 & 0 & & & & & 2005 & 0 \\
\hline 6 & 2010 & 0 & 1.34 & 0.16 & 1.64 & 0.20 & 2002 & 0 \\
\hline 8 & 2008 & 1 & 1.03 & 0.13 & 1.22 & 0.15 & 1999 & 0 \\
\hline 10 & 2005 & 1 & 0.67 & 0.08 & 0.69 & 0.08 & 1996 & 0 \\
\hline 12 & 2001 & 1 & 0.49 & 0.06 & 0.43 & 0.05 & 1992 & 0 \\
\hline 14 & 1998 & 2 & 0.63 & 0.08 & 0.64 & 0.08 & 1989 & 1 \\
\hline 16 & 1997 & 2 & 1.47 & 0.18 & 1.92 & 0.23 & 1986 & 1 \\
\hline 18 & 1995 & 2 & 1.09 & 0.13 & 1.12 & 0.14 & 1983 & 1 \\
\hline 20 & 1991 & 3 & 0.46 & 0.06 & 0.47 & 0.06 & 1979 & 1 \\
\hline 22 & 1986 & 3 & 0.37 & 0.05 & 0.45 & 0.05 & 1976 & 1 \\
\hline 24 & 1984 & 3 & 0.95 & 0.12 & 1.11 & 0.14 & 1973 & 1 \\
\hline 26 & 1984 & 3 & & & & & 1970 & 1 \\
\hline 28 & 1984 & 3 & & & & & 1966 & 1 \\
\hline 30 & 1984 & 3 & & & & & 1963 & 1 \\
\hline 32 & 1982 & 4 & 0.86 & 0.10 & 1.01 & 0.12 & 1960 & 1 \\
\hline 34 & 1976 & 4 & 0.35 & 0.04 & 0.44 & 0.05 & 1956 & 1 \\
\hline 36 & 1972 & 5 & 0.46 & 0.06 & 0.57 & 0.07 & 1953 & 1 \\
\hline 38 & 1970 & 5 & 0.77 & 0.09 & 1.09 & 0.13 & 1950 & 2 \\
\hline 40 & 1966 & 6 & 0.60 & 0.07 & 0.74 & 0.09 & 1947 & 2 \\
\hline 46 & 1964 & 6 & 0.77 & 0.09 & 0.96 & 0.12 & 1937 & 2 \\
\hline 50 & 1962 & 6 & 0.83 & 0.10 & 0.85 & 0.10 & 1930 & 2 \\
\hline 54 & 1956 & 7 & 0.41 & 0.05 & 0.43 & 0.05 & 1924 & 2 \\
\hline 58 & 1952 & 7 & 0.30 & 0.04 & 0.29 & 0.04 & 1917 & 2 \\
\hline 60 & 1938 & 9 & 0.16 & 0.02 & 0.16 & 0.02 & 1914 & 2 \\
\hline 70 & 1925 & 11 & 0.08 & 0.01 & 0.10 & 0.01 & 1898 & 3 \\
\hline 80 & 1887 & 15 & 0.04 & 0.00 & 0.03 & 0.00 & 1881 & 3 \\
\hline 90 & 1814 & 24 & 0.01 & 0.00 & 0.01 & 0.00 & 1865 & 3 \\
\hline
\end{tabular}


Table S10. Correlation matrix of mud content and the analyzed elements in the sediment cores

\begin{tabular}{|c|c|c|c|c|c|c|c|c|c|}
\hline & \%Mud & As & $\mathrm{Cr}$ & $\mathrm{Cu}$ & $\mathrm{Ni}$ & $\mathrm{Pb}$ & Sc & $\mathbf{V}$ & $\mathrm{Zn}$ \\
\hline \multicolumn{10}{|l|}{ a (S1) } \\
\hline$\%$ Mud & 1 & & & & & & & & \\
\hline As & 0.45 & 1 & & & & & & & \\
\hline $\mathrm{Cr}$ & $0.93^{* *}$ & $0.48^{* *}$ & 1 & & & & & & \\
\hline $\mathrm{Cu}$ & 0.14 & 0.21 & $0.39 *$ & 1 & & & & & \\
\hline $\mathrm{Ni}$ & $0.93 * *$ & $0.54 * *$ & $0.99 * *$ & $0.42^{*}$ & 1 & & & & \\
\hline $\mathrm{Pb}$ & $0.55^{* *}$ & $0.40^{*}$ & $0.68 * *$ & $0.73^{* *}$ & $0.70 * *$ & 1 & & & \\
\hline Sc & $0.92 * *$ & $0.38^{*}$ & $0.99 * *$ & $0.39 * *$ & $0.98 * *$ & $0.65^{* *}$ & 1 & & \\
\hline V & $0.86^{* *}$ & $0.51^{* *}$ & $0.96 * *$ & 0.33 & $0.95^{* *}$ & $0.57^{* *}$ & $0.95^{* *}$ & 1 & \\
\hline $\mathrm{Zn}$ & $0.75^{* *}$ & $0.44^{* *}$ & $0.90 * *$ & $0.67^{* *}$ & $0.92 * *$ & $0.78^{* *}$ & $0.90 * *$ & $0.87^{* *}$ & 1 \\
\hline \multicolumn{10}{|l|}{ b (S2) } \\
\hline \%Mud & 1 & & & & & & & & \\
\hline As & $0.82 * *$ & 1 & & & & & & & \\
\hline $\mathrm{Cr}$ & $0.84 * *$ & $0.84^{* *}$ & 1 & & & & & & \\
\hline $\mathrm{Cu}$ & $0.93^{* *}$ & $0.81^{* *}$ & $0.93 * *$ & 1 & & & & & \\
\hline $\mathrm{Ni}$ & $0.69 * *$ & $0.79 * *$ & $0.93^{* *}$ & $0.85 * *$ & 1 & & & & \\
\hline $\mathrm{Pb}$ & $0.75 * *$ & $0.63^{* *}$ & $0.73^{* *}$ & $0.75 * *$ & $0.58 * *$ & 1 & & & \\
\hline Sc & $0.89 * *$ & $0.86^{* *}$ & $0.96 * *$ & $0.92 * *$ & $0.86^{* *}$ & $0.66 * *$ & 1 & & \\
\hline $\mathrm{V}$ & $0.91 * *$ & $0.88^{* *}$ & $0.97 * *$ & $0.93 * *$ & $0.86 * *$ & $0.72 * *$ & $0.99 * *$ & 1 & \\
\hline $\mathrm{Zn}$ & $0.47 * *$ & $0.41^{* *}$ & $0.62 * *$ & $0.62 * *$ & $0.63 * *$ & $0.81^{* *}$ & $0.46^{* *}$ & $0.51^{* *}$ & 1 \\
\hline \multicolumn{10}{|l|}{ c (S3) } \\
\hline$\%$ Mud & 1 & & & & & & & & \\
\hline As & 0.55 & 1 & & & & & & & \\
\hline $\mathrm{Cr}$ & $0.81 * *$ & $0.78^{* *}$ & 1 & & & & & & \\
\hline $\mathrm{Cu}$ & $0.37 * *$ & $0.84 * *$ & 0.60 & 1 & & & & & \\
\hline $\mathrm{Ni}$ & $0.82 * *$ & $0.80 * *$ & $0.99 * *$ & $0.65 * *$ & 1 & & & & \\
\hline $\mathrm{Pb}$ & $0.67 * *$ & $0.88^{* *}$ & $0.89 * *$ & $0.85 * *$ & $0.91 * *$ & 1 & & & \\
\hline Sc & $0.83 * *$ & $0.68^{* *}$ & $0.98 * *$ & $0.44 * *$ & $0.96 * *$ & $0.79 * *$ & 1 & & \\
\hline $\mathrm{V}$ & $0.75^{* *}$ & $0.84^{* *}$ & $0.96 * *$ & $0.66 * *$ & $0.97 * *$ & $0.87^{* *}$ & $0.93^{* *}$ & 1 & \\
\hline $\mathrm{Zn}$ & $0.48 * *$ & $0.83^{* *}$ & $0.71^{* *}$ & $0.96 * *$ & $0.75^{* *}$ & $0.91 * *$ & $0.56^{* *}$ & $0.71^{* *}$ & 1 \\
\hline \multicolumn{10}{|l|}{ d (S4) } \\
\hline \%Mud & 1 & & & & & & & & \\
\hline As & $0.74^{*}$ & 1 & & & & & & & \\
\hline $\mathrm{Cr}$ & $0.88 * *$ & $0.90^{* *}$ & 1 & & & & & & \\
\hline $\mathrm{Cu}$ & $0.85 * *$ & $0.80 * *$ & $0.96^{* *}$ & 1 & & & & & \\
\hline $\mathrm{Ni}$ & $0.87^{* *}$ & $0.90^{* *}$ & $0.99 * *$ & $0.96 * *$ & 1 & & & & \\
\hline $\mathrm{Pb}$ & $0.88 * *$ & $0.87^{* *}$ & $0.98^{* *}$ & $0.97 * *$ & $0.97^{* *}$ & 1 & & & \\
\hline Sc & $0.88 * *$ & $0.89 * *$ & $0.99 * *$ & $0.96 * *$ & $0.99 * *$ & $0.97 * *$ & 1 & & \\
\hline $\mathrm{V}$ & $0.84^{* *}$ & $0.90 * *$ & $0.99 * *$ & $0.94 * *$ & $0.99 * *$ & $0.96 * *$ & $0.99 * *$ & 1 & \\
\hline $\mathrm{Zn}$ & $0.86 * *$ & $0.84^{* *}$ & $0.95^{* *}$ & $0.98 * *$ & $0.95^{* *}$ & $0.98 * *$ & $0.94^{* *}$ & $0.93 * *$ & 1 \\
\hline
\end{tabular}

Note: ** Pearson correlation significance at the 0.01 level; * Pearson correlation significance at the 0.05 level 


\section{Figures}
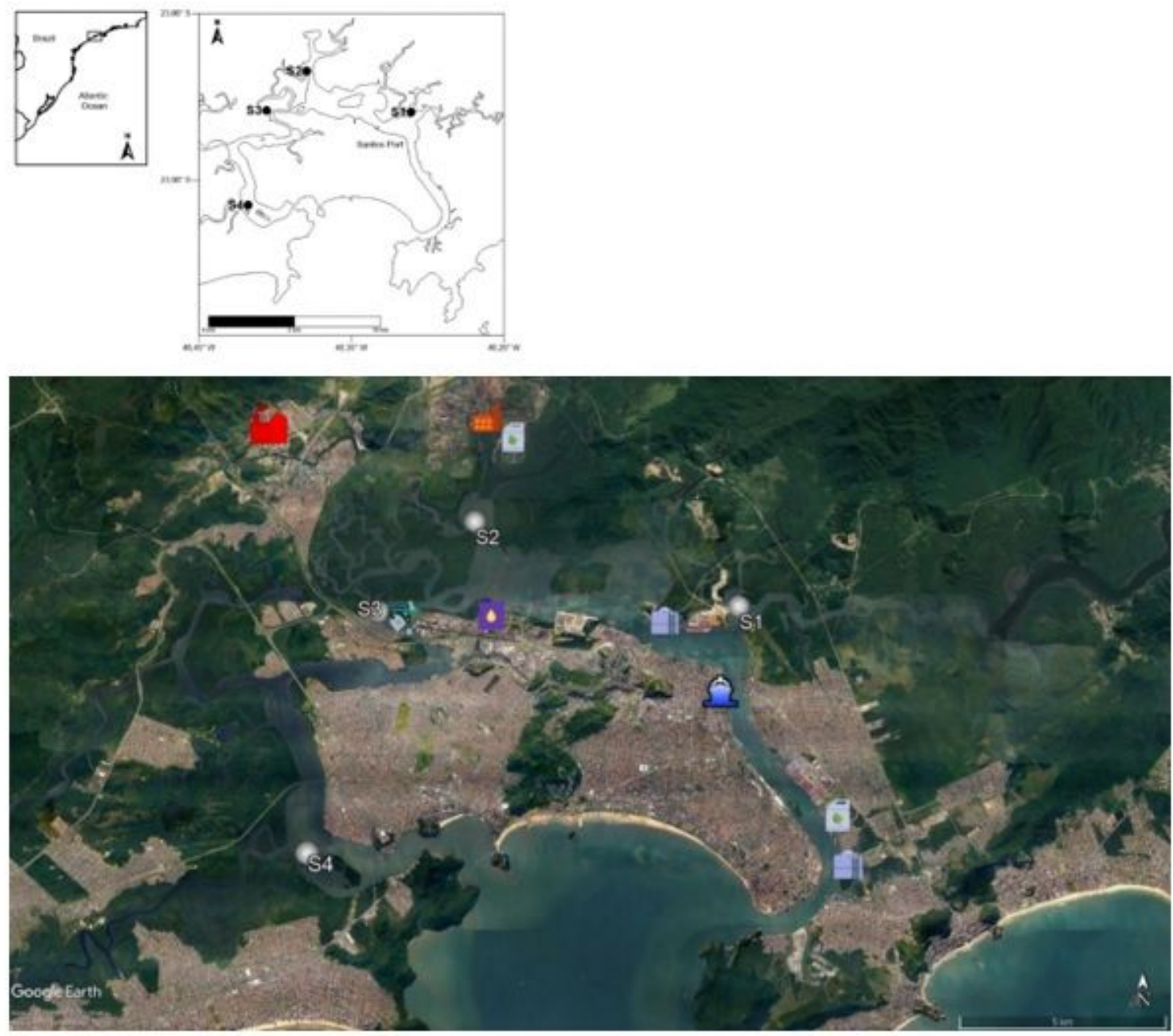

\begin{tabular}{|l|l|}
\hline Cubatão Industrial \\
Complex
\end{tabular}

\section{Figure 1}

Sampling locations (S1, S2, S3 and S4) and possible pollution sources along the Santos and São Vicente estuarine system. 


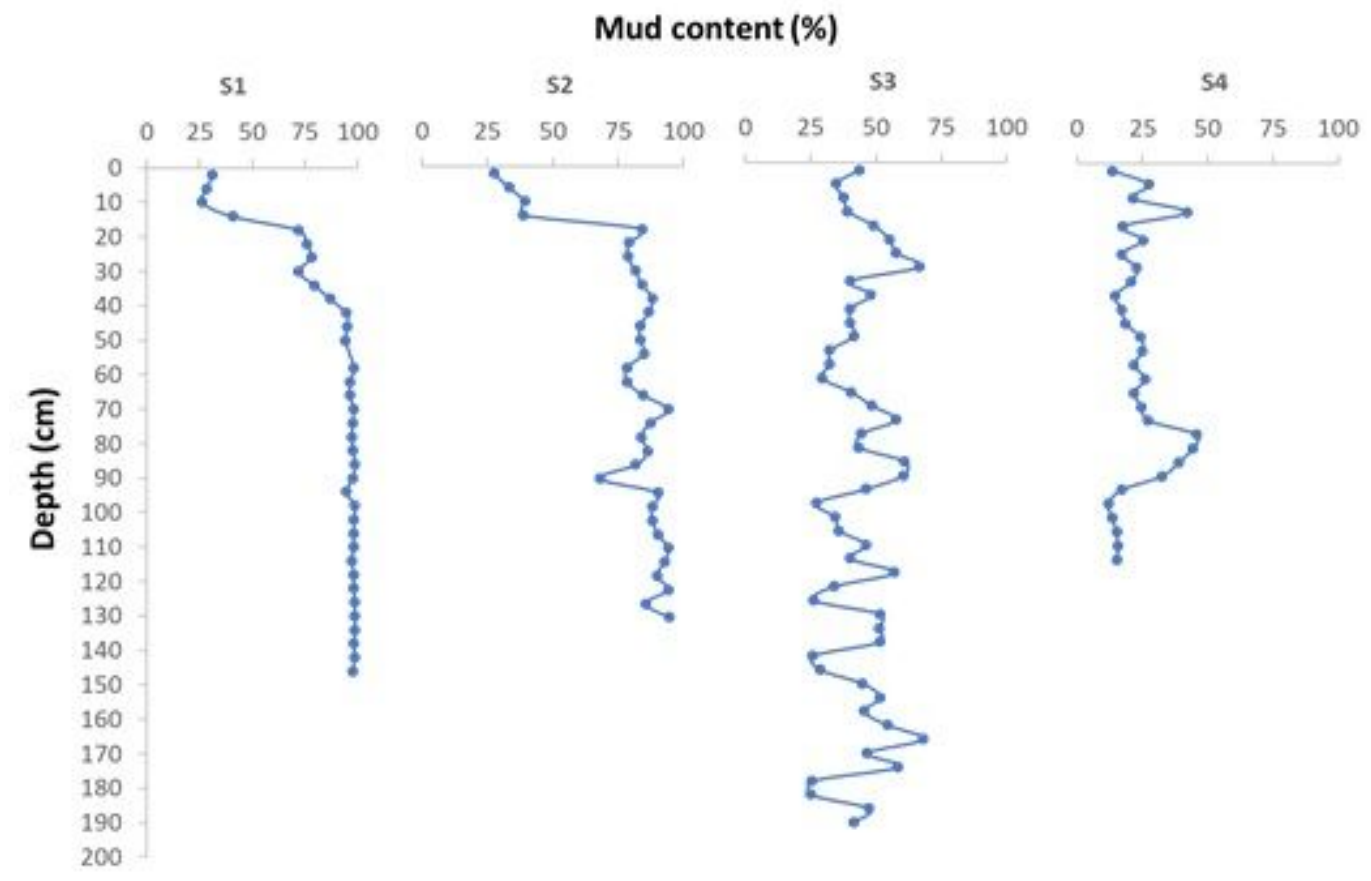

Figure 2

Vertical distribution of Mud content (\%) along with the sediment cores.

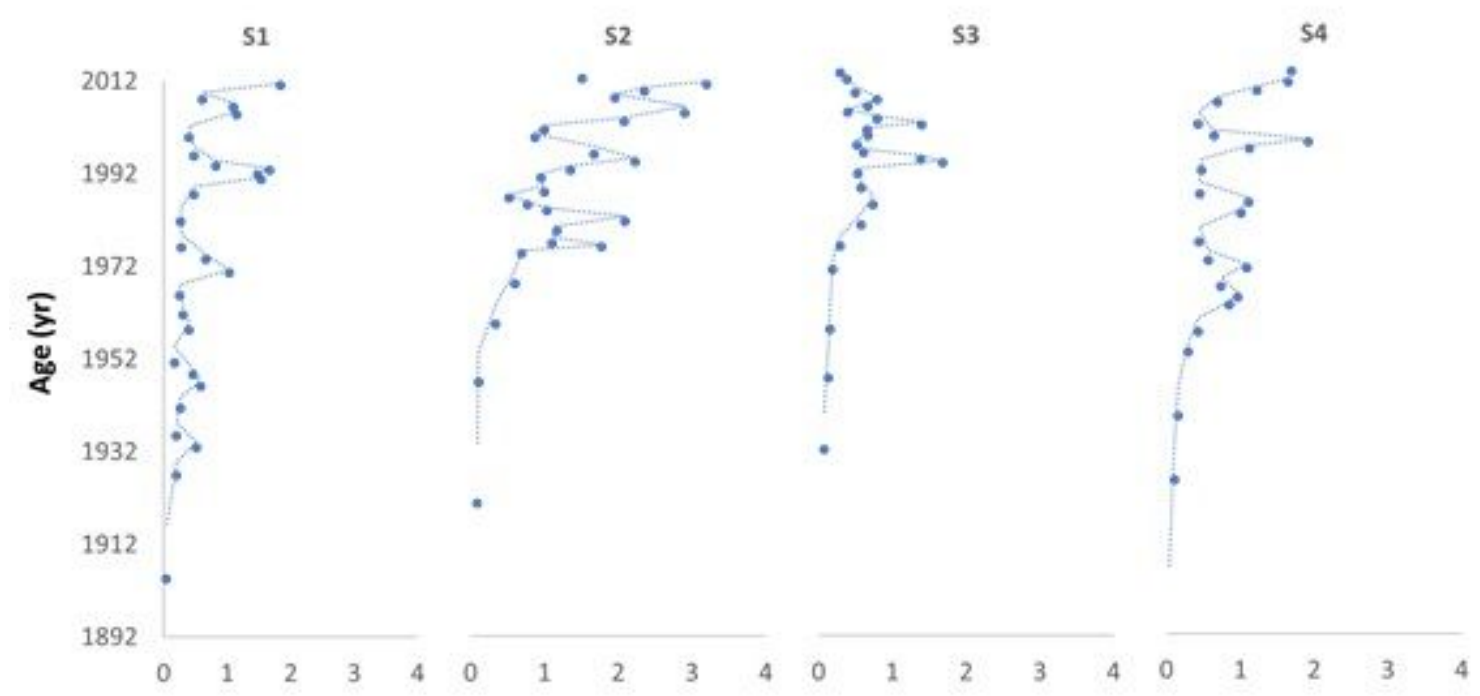

Figure 3

Mass accumulation rates ( $\mathrm{g} \mathrm{cm}-2 \mathrm{yr}-1$ vs dating of cores from the SSVES. 


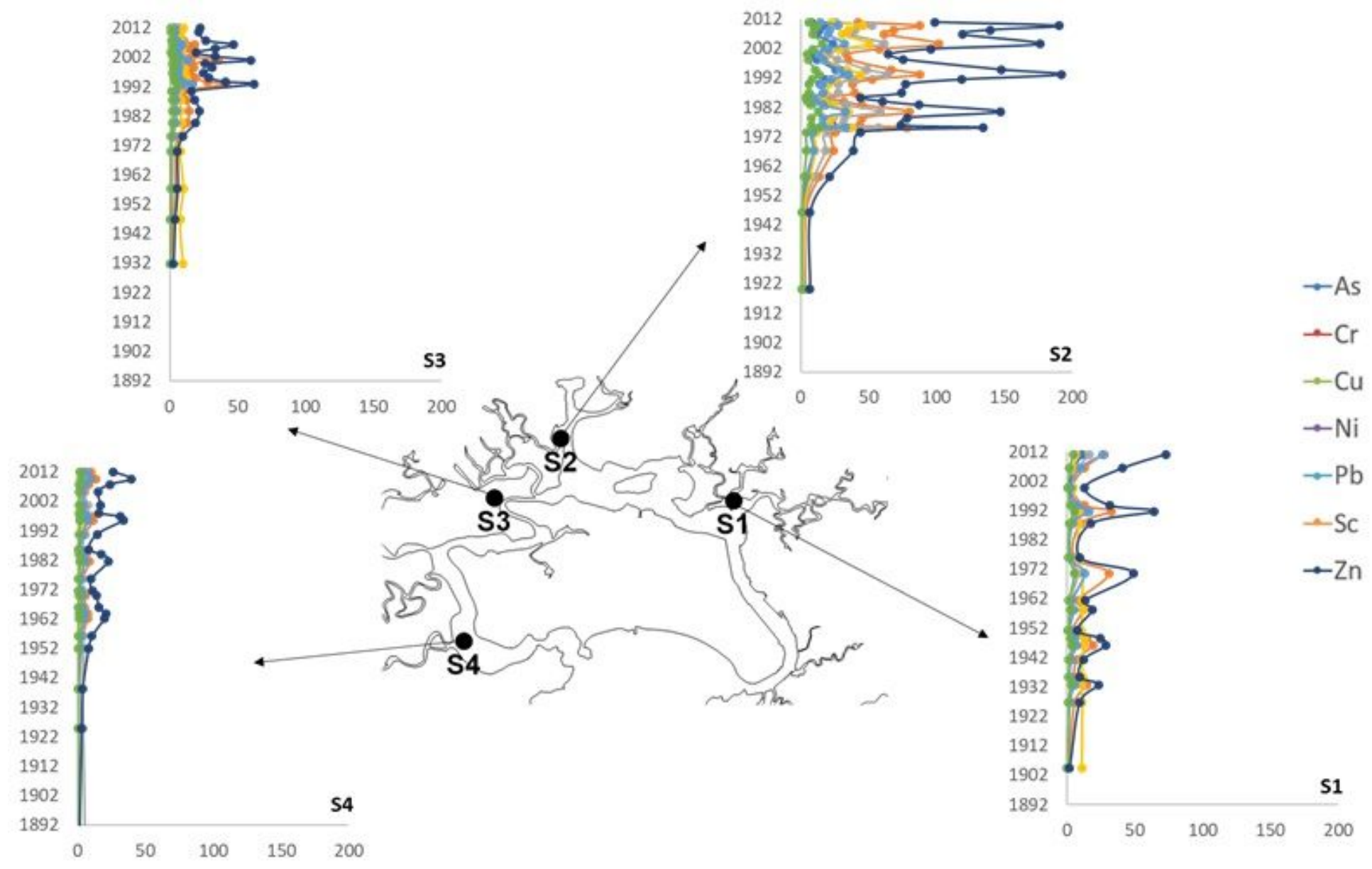

Figure 4

Trace element fluxes (mg cm-2yr-1) along the sediment cores of the SSVES. 

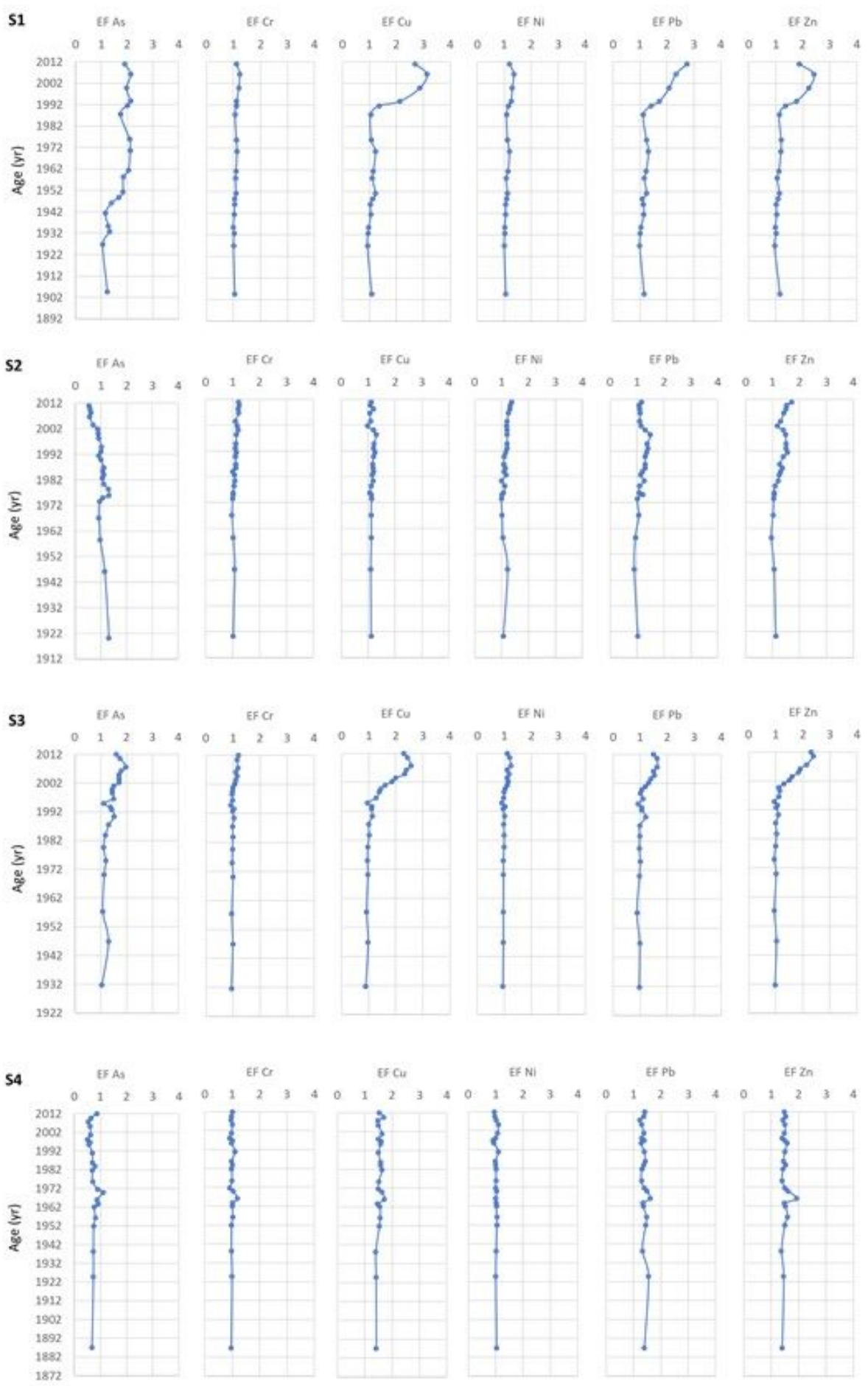

\section{Figure 5}

Enrichment Factor (EF) of trace elements from the SSVES sediment cores. 
S1

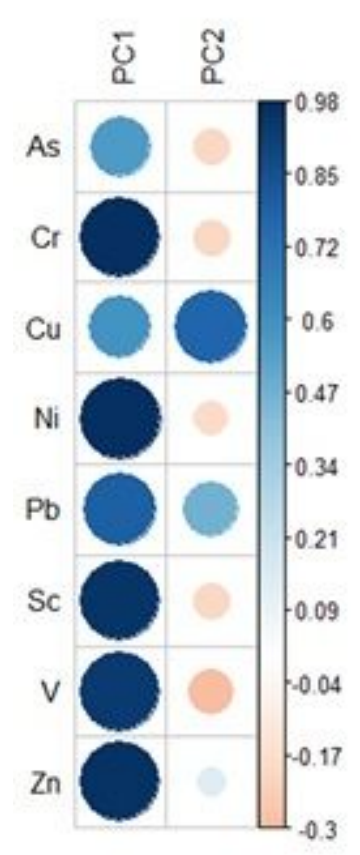

S2

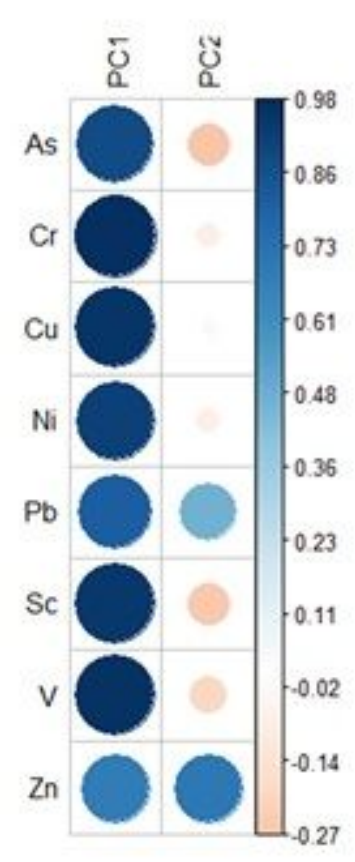

S3

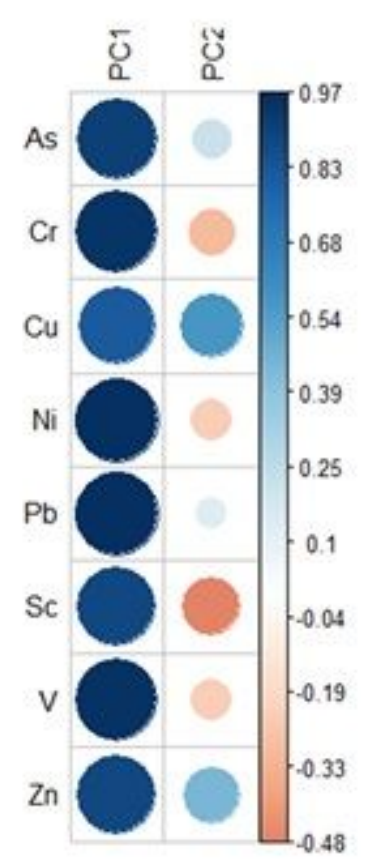

S4

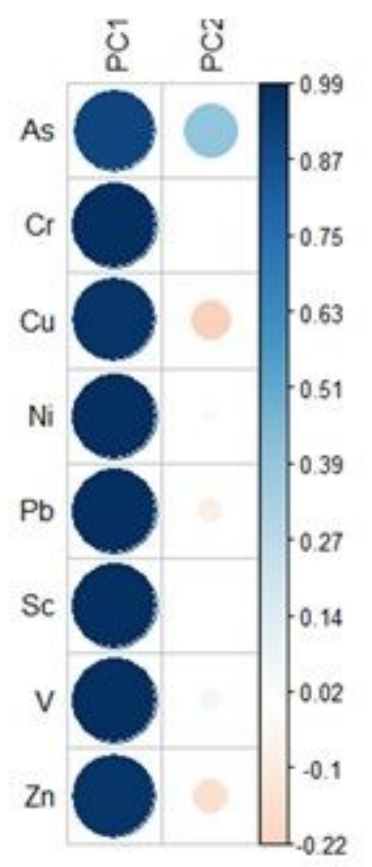

Figure 6

Loading plots from the PCA of the SSVES sediment cores. 